\title{
Codici, spazi, processi. I monasteri del Monte Athos
}

\author{
Luigi Corniello \\ Gennaro Pio Lento \\ Angelo De Cicco
}

Abstract

Lo studio propone i risultati delle campagne di rilievo architettonico, condotte dal luglio 2020, lungo la fascia costiera occidentale della penisola dell'Athos in Grecia.

Scarna è l'attuale documentazione bibliografica incentrata, nella maggior parte dei volumi, su una descrizione storico artistica delle opere pittoriche presenti nei monasteri nonché su taccuini di viaggio dei visitatori.

Attraverso le fasi consolidate della disciplina della rappresentazione, quali rilievo digitale, nuvola dei punti, elaborazione delle superfici piane e modellazione 3D, si propone un percorso di conoscenza del terzo braccio della penisola Calcidica relativamente alle architetture religiose.

Le ricerche sono state sviluppate, nella parte iniziale, con documentazione fotografica dal mare, mentre, in una successiva fase si è proceduto al rilievo in situ dei monasteri della costa occidentale. Le attività di rilievo strumentale, realizzate attraverso l'ausilio di droni quadrielica e fotogrammetria terrestre, hanno interessato il Monastero di San Dionisio, il Monastero di Xeropotamo, il Monastero dello Zografo, il Monastero del Dochiario, il Monastero di Simonpetra, il Monastero di San Paolo, il Monastero di Senofonte, il Monastero di San Gregorio, il Monastero di San Pantaleimon e il Monastero di Costamonita.

La ricerca mira a esporre, per la prima volta, i rilievi inediti strumentali eseguiti nella comunità dell'Athos, avversa da secoli all'accesso di turisti e curiosi.

Parole chiave

rilevo, fotogrammetria, tecnologie, monasteri, Athos.

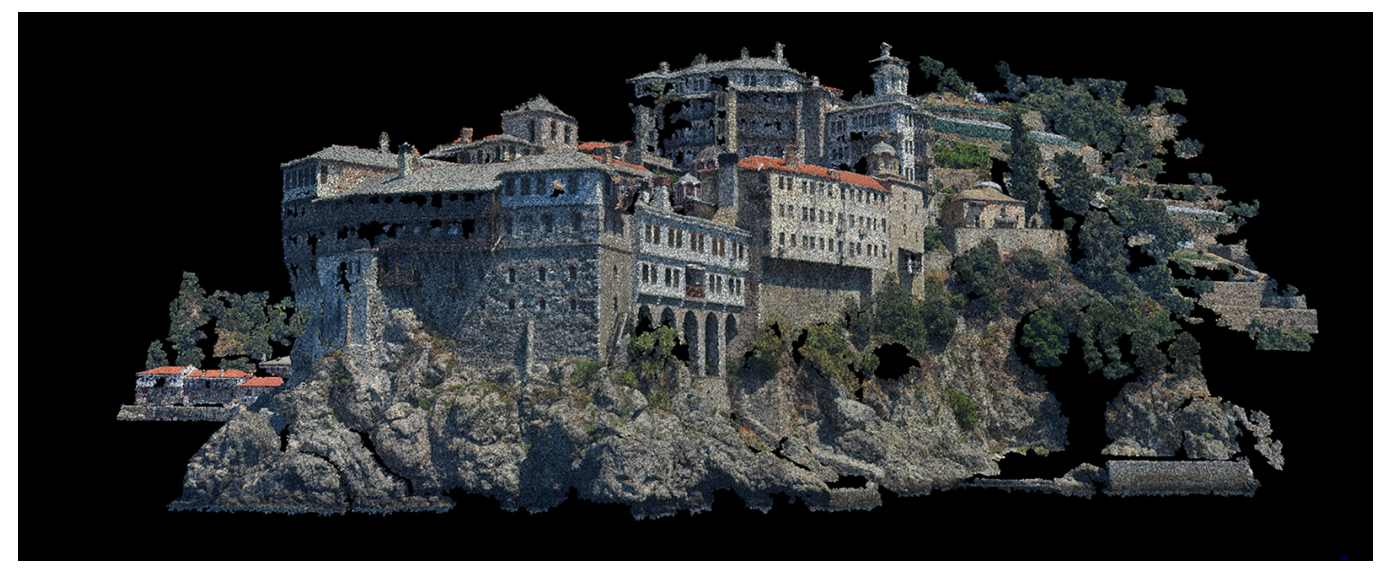




\section{Introduzione}

II contributo presenta i risultati delle campagne di rilievo architettonico, condotte nei mesi di luglio e agosto 2020, lungo la fascia costiera occidentale della penisola del Monte Athos, un territorio autonomo interno alla Repubblica Ellenica ma dotato di uno statuto speciale di autogoverno, sito presso l'ultima delle tre penisole della regione chiamata Calcidica.

L'attuale documentazione bibliografica incentrata, nella maggior parte dei volumi, a una descrizione storico artistica delle opere pittoriche presenti nei monasteri nonché a taccuini di viaggio dei visitatori che ne hanno scalato vette e ripidi sentieri è scarna nella documentazione grafica e nei rilievi dei volumi architettonici.

Numerosi sono i viaggiatori celebri (architetti, filosofi, scrittori, registi) che dalle pendici della Montagna Sacra hanno tratto ispirazione per le loro opere: il famoso romanzo II nome della rosa di Umberto Eco è stato ispirato dal suo viaggio nell'Athos. Anche Le Corbusier visita il Monte e alcuni riferimenti sono individuabili nel suo lavoro del 1960 ovvero il Monastero Cattolico di Tourette a Lione, in Francia, la cui struttura può essere paragonata al complesso monastico di Dionisiou.

Nel corso dei secoli la comunità monastica dell'Athos, dedita alla vita eremitica, ha custodito le tradizioni sociali dei circa 1500 monaci ortodossi e le geometrie architettoniche degli edifici comunitari, delle chiese, delle strutture di servizio, dei dormitori e delle celle solitarie.

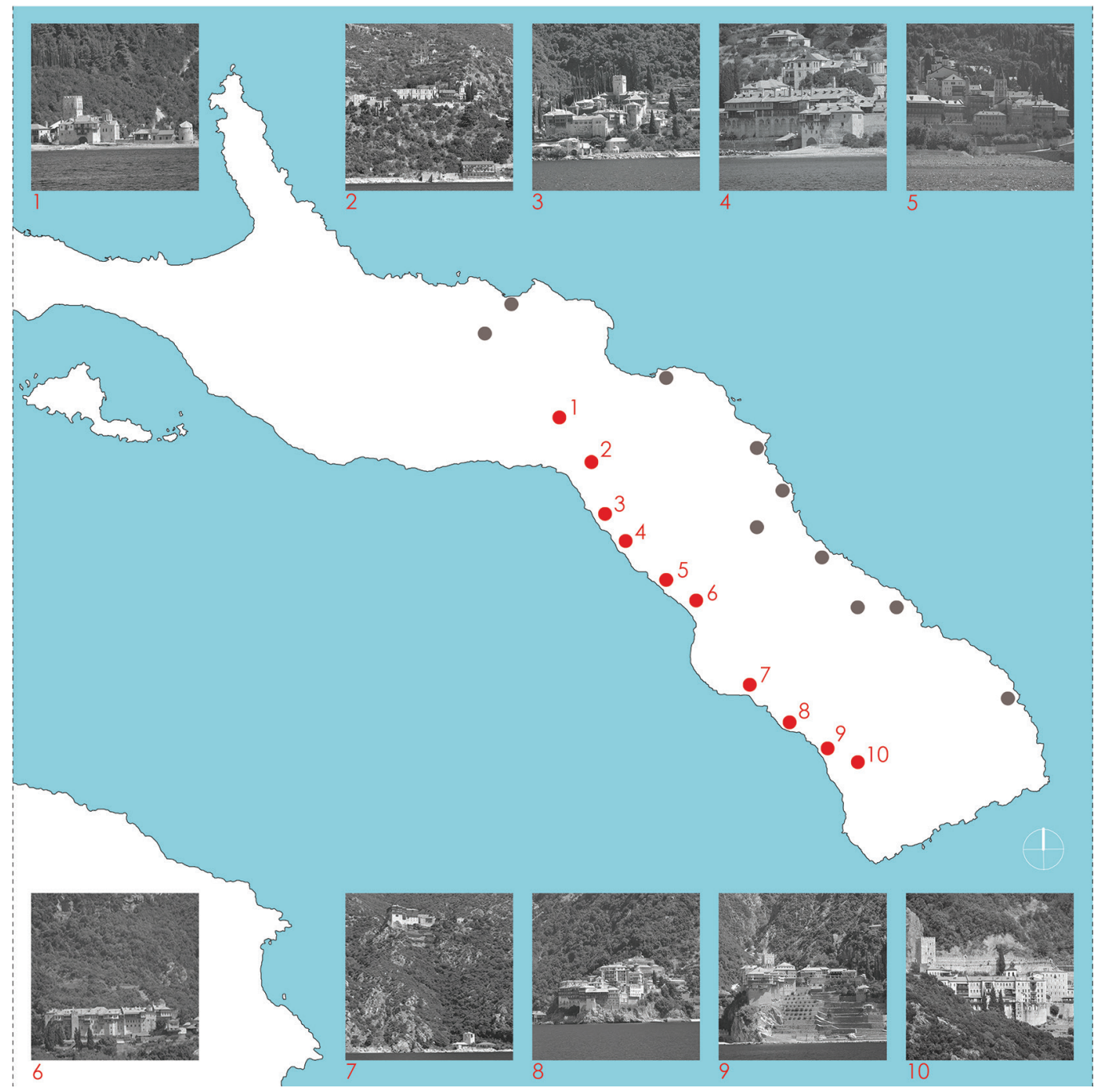




\section{Gli spazi architettonici}

Nella definizione della ricerca risulta di particolare interesse lo studio degli spazi in cui si svolge la vita monastica. Le attività hanno interessato il Monastero di San Dionisio, il Monastero di Xeropotamo, il Monastero dello Zografo, il Monastero del Dochiario, il Monastero di Simonpetra, il Monastero di San Paolo, il Monastero di Senofonte, il Monastero di San Gregorio, il Monastero di San Pantaleimon e il Monastero di Costamonita.

II Monastero di Dionisiou, costruito nella metà del XIV secolo dal monaco Dionysious di Koryssos, fu distrutto nel I 535 da un incendio e, successivamente ricostruito conservandone, fino ai giorni nostri, la sua forma architettonica. Le strutture, realizzate su uno sperone di roccia a picco sul mare, risultano di minori dimensioni rispetto alla superfice calpestabile degli altri complessi. Il monastero è caratterizzato da una chiesa centrale contornata da varie cappelle con affreschi e un refettorio terminato nel I603. Di particolare interesse è la torre difensiva, costruita nel 1520, che attualmente custodisce la preziosa biblioteca del Monastero con numerose opere d'arte tra le quali icone e manoscritti miniati.

II Monastero di Xenophontos è sito in riva al mare, tra le strutture di Docheiariou e San Panteleimonos, ed è dedicato a San Giorgio. Nella bibliografia storica viene citato nel XI sec., quando dopo una lunga attività commerciale e culturale viene distrutto e ricostruito. La quinta a mare presenta una grande apertura d'ingresso sovrastata da quattro piani di cui uno mansardato. La parte inferiore della costruzione è caratterizzata da una struttura in

(1)
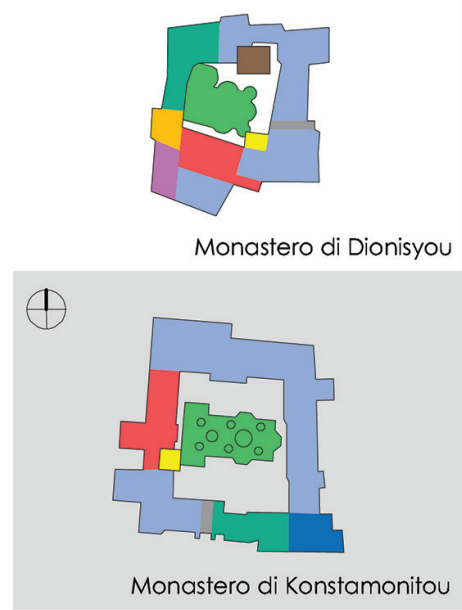

(1)

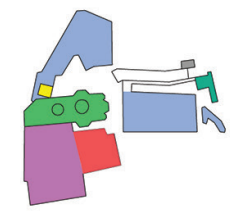

Monastero di Simonos Petras

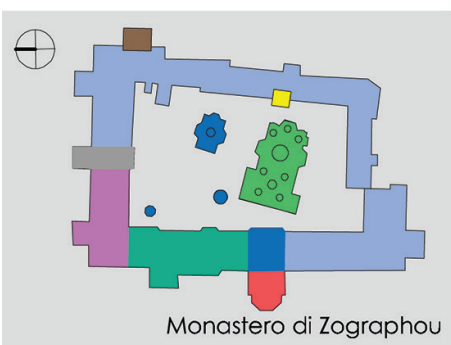

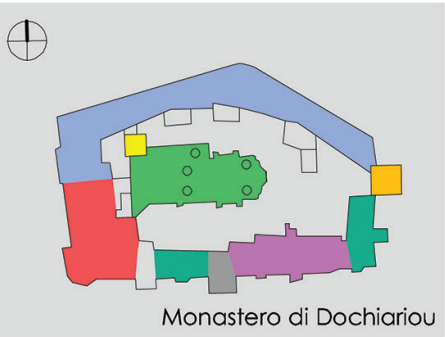

$\theta$
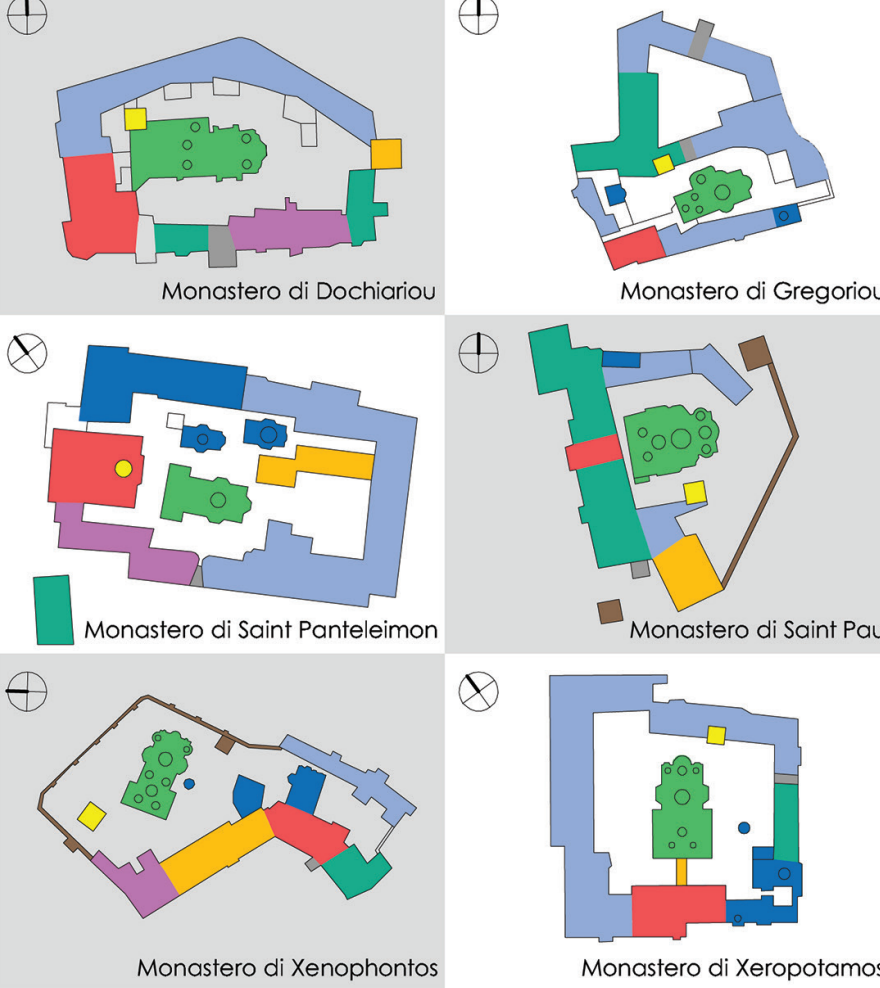

Legenda

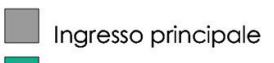

Camere degli ospiti

$\square$ Chiesa principale

Refettorio

Campanile

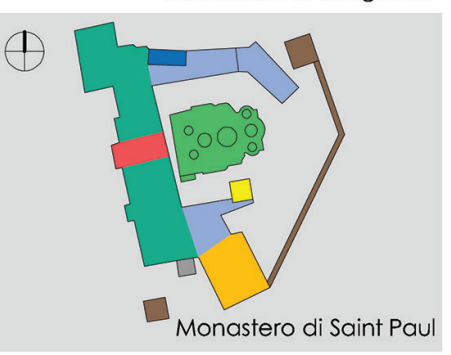

$\otimes$

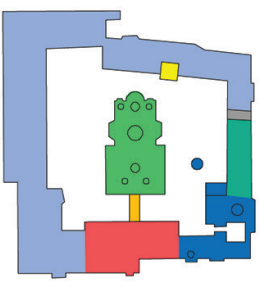

Monastero di Xeropotamos 
Fig. 3. II Monastero di San realizzata dal mare.

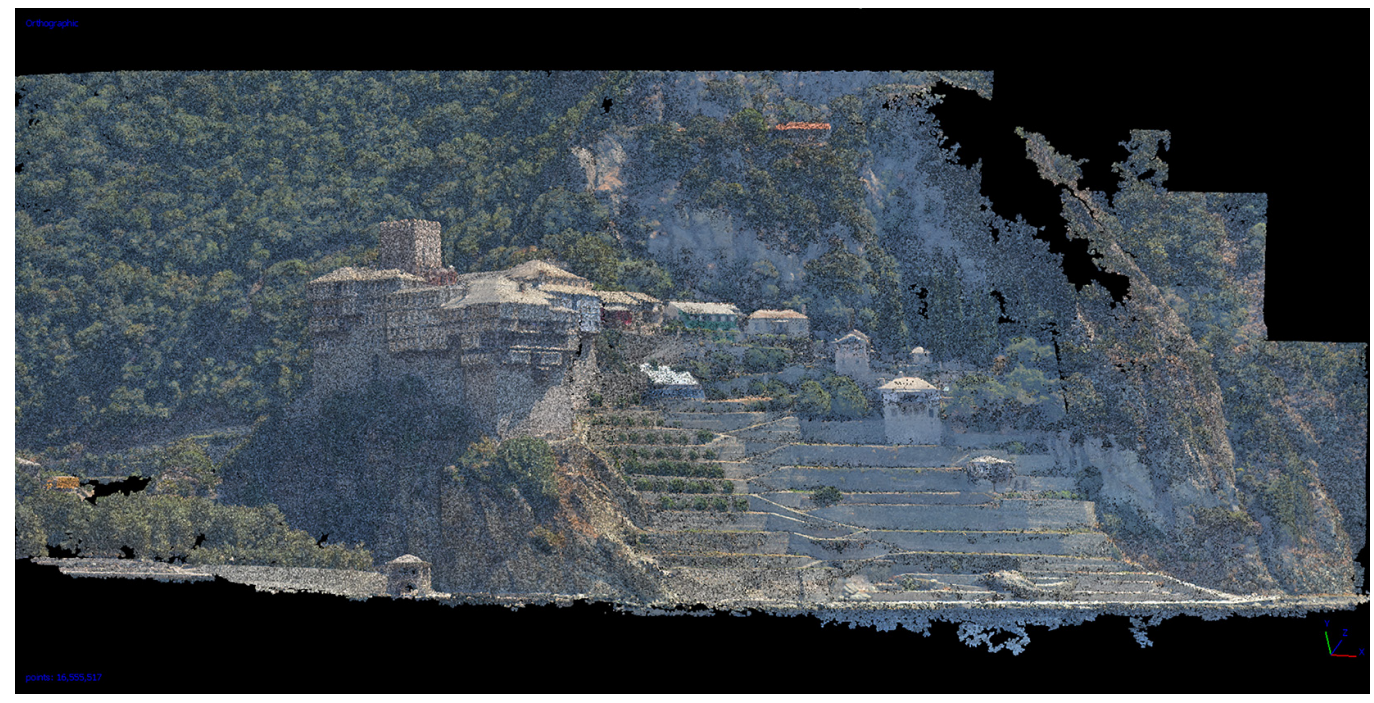

pietra con archi e contrafforti sormontata da ballatoi in legno colorato in rosso e azzurro. Di grande interesse è la biblioteca dove sono presenti 300 manoscritti, oltre 4.000 libri e numerose icone in mosaico.

II Monastero di Zografo fondato secondo la tradizione nel X sec., è dedicato a San Giorgio e situato su un pendio della parte sud-ovest della penisola del Monte Athos. Nel periodo tardo bizantino viene distrutto dai pirati e ricostruito con il sostegno finanziario dei sovrani dell'Europa orientale. Per tale motivazione, la prevalenza dei monaci residenti proveniva dalla Bulgaria, dalla Serbia e in parte, dalla Grecia. I volumi che caratterizzano le strutture nella corte centrale sono ricoperti da cupole in zinco ramato. Sono, inoltre presenti due laboratori per la pittura e la realizzazione di icone religiose e una biblioteca con 126 manoscritti in lingua greca e 388 in lingua slava.

II Monastero di Dochiariou, sito in riva al mare, fu fondato nella seconda metà del X secolo. La struttura, attualmente, è raggiungibile attraverso un molo di attracco per piccole e medie imbarcazioni atte a rifornire di beni non autoprodotti. II complesso monastico si sviluppa sul pendio della montagna con diverse forme geometriche quali i parallelepipedi dei volumi principali, le sfere e le semisfere delle cupole delle chiese e delle cappelle, le piramidi e i coni delle coperture. Di notevole intessere sono i due refettori posizionati parallelamente alla

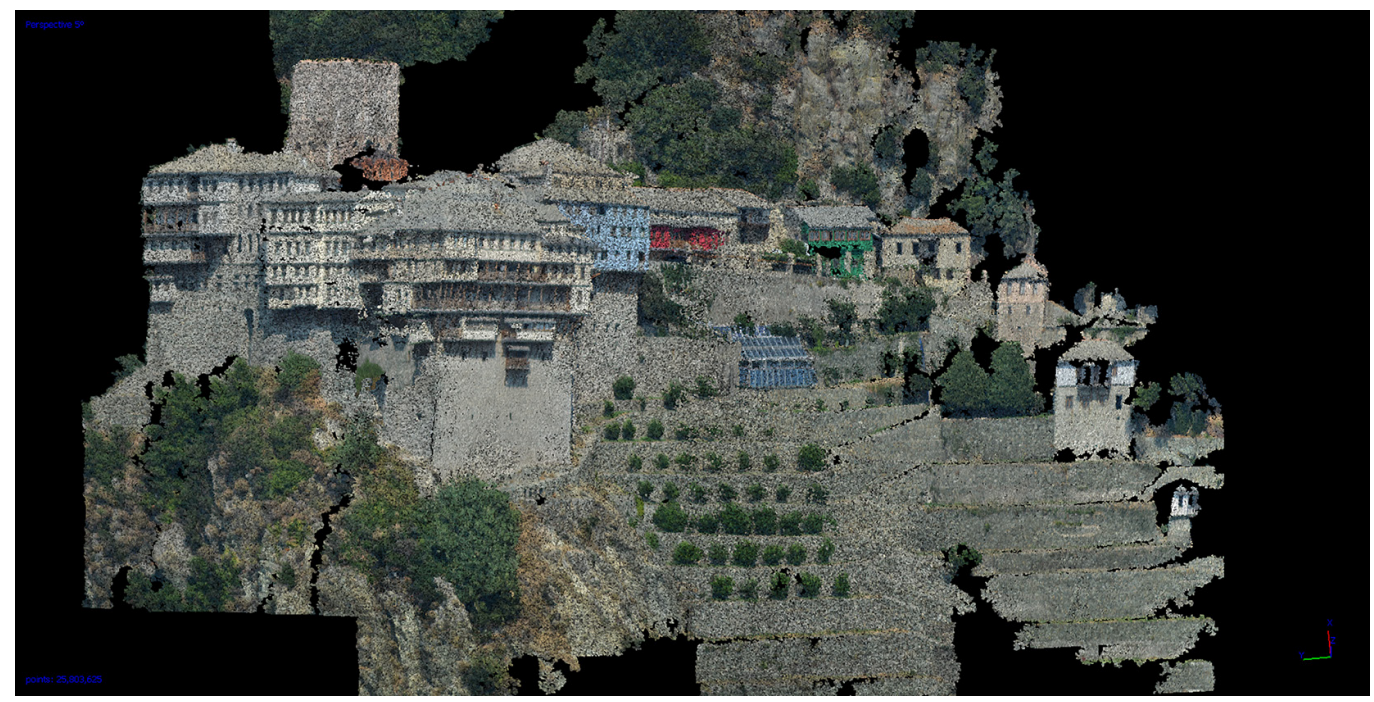

Fig. 4. Il Monastero di San ola dei punti realizzata da drone. 
linea di costa con il refettorio vecchio sul mare, databile al I675, e quello nuovo in collina del I700, sovrastati dal Katholikon, ovvero la chiesa principale edificata sui resti delle mura di un edificio religioso più antico. II Monastero presenta, inoltre, una torre di guardia e una biblioteca con circa 900 manoscritti.

Il Monastero di Simonopetra è caratterizzato da un maestoso edificio a sette piani ed è dedicato alla nascita del Cristo. La struttura sita a 230 metri sul livello del mare è composta da due complessi architettonici posizionati rispettivamente a valle, con funzione di approdo per le imbarcazioni provenienti dai centri abitati della vicina Ouranopoli, e a monte, owero la residenza dei monaci e i luoghi della preghiera. II corpo di fabbrica sul mare, dotato di piccolo porto e rimessa per le barche presenta una torre di guardia in pietra. In posizione panoramica, rivolta verso sud, il Monastero è composto da due porzioni edificate: la prima con la chiesa, il refettorio e una torre; la seconda, invece, interamente adibita alle residenze per i monaci con celle e servizi. Nel corso dei secoli, il fabbricato è stato distrutto da numerosi incendi e più volte ricostruito attraverso donazioni provenienti dalla Russia.

II Monastero di San Paolo, dedicato alla presentazione del Cristo al Tempio, fu distrutto e ricostruito numerose volte nel corso dei secoli: tale stratificazione architettonica è individuabile nelle forme delle costruzioni risalenti a epoche diverse. II complesso religioso, attualmente frequentato da una comunità di 30 monaci, presenta 12 cappelle per la preghiera di cui, la più importante, è quella dedicata a San Giorgio, con affreschi di scuola cretese risalenti al I555. Di grande interesse è la biblioteca contenente 494 manoscritti e un totale di circa 12.500 libri.
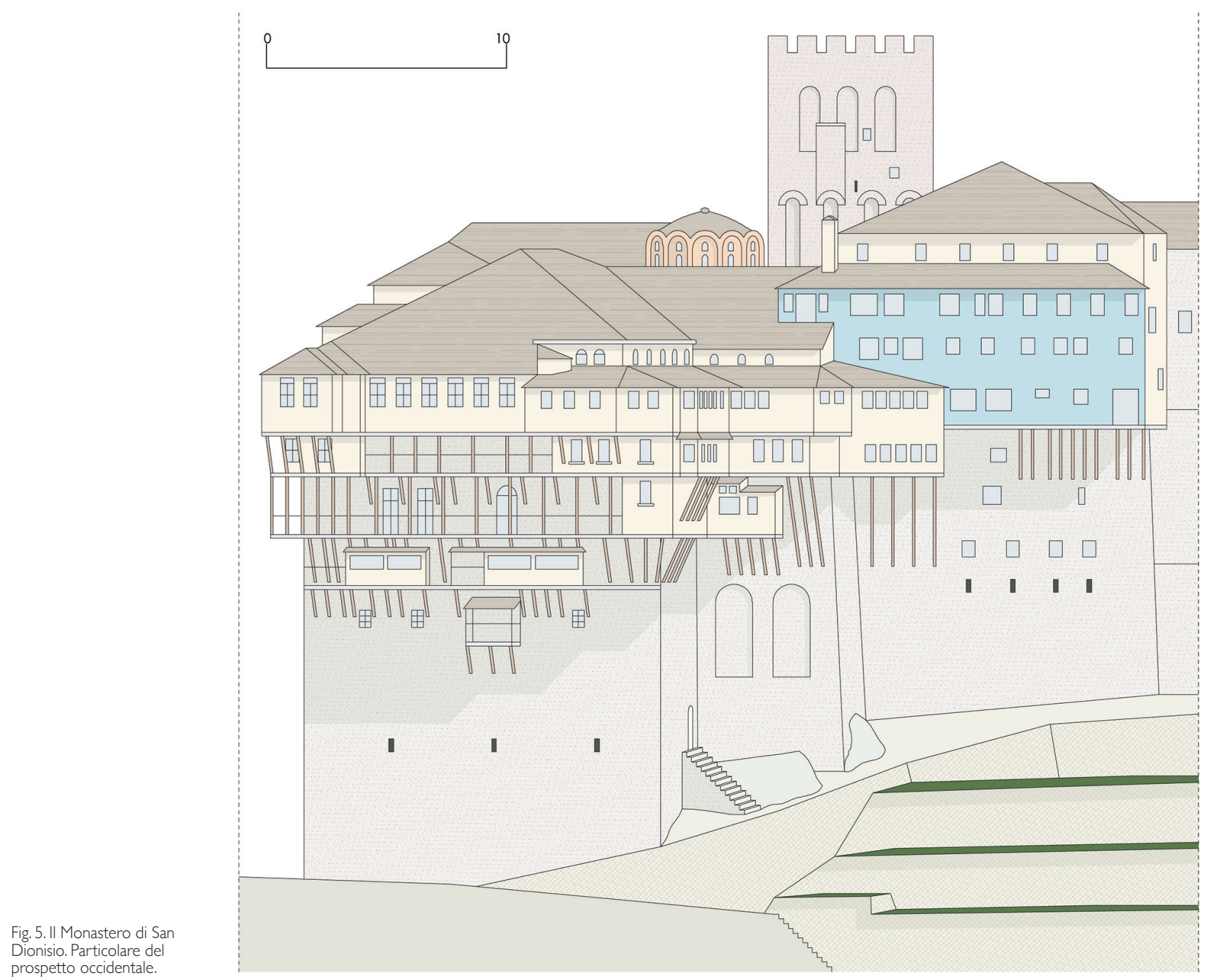


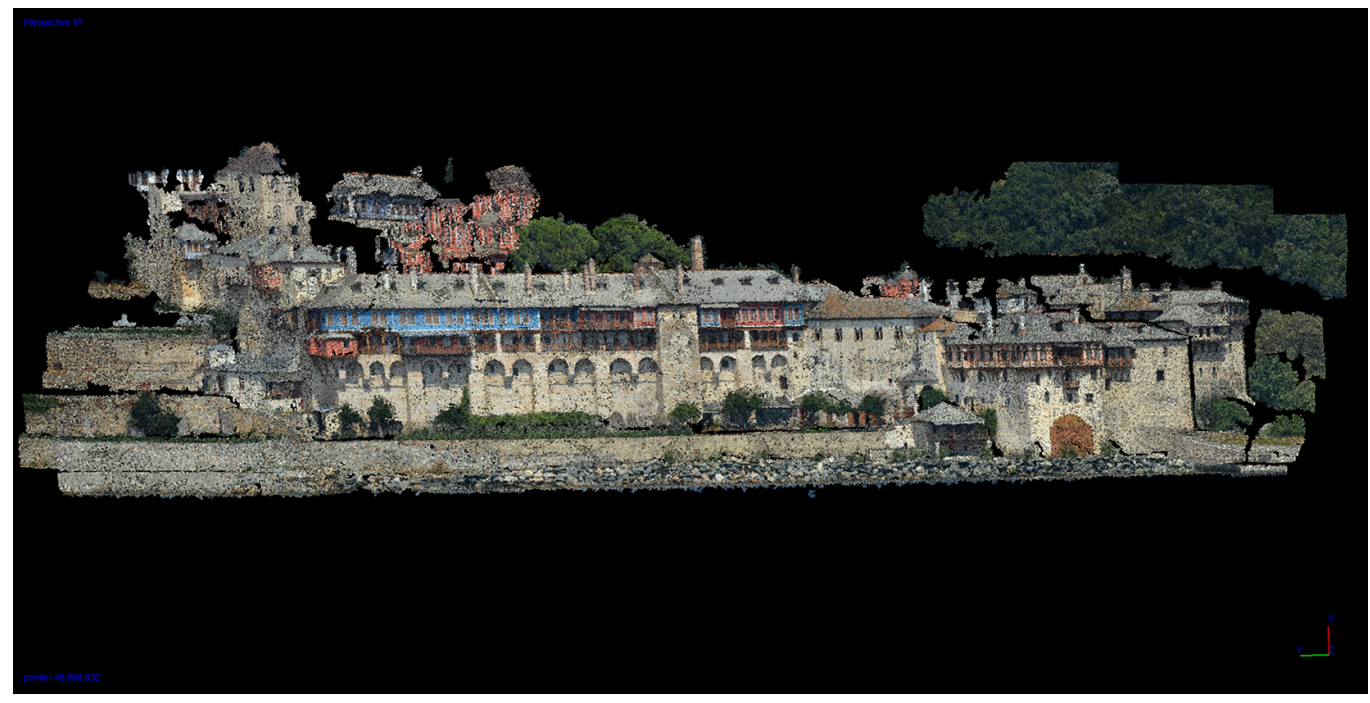

II Monastero di Grigoriou, attualmente abitato da una confraternita di 70 monaci, è costruito in riva al mare, nel lato sud-ovest della penisola, tra i monasteri di Dionysiou e Simonopetra ed è dedicato a San Nicola. La quinta edificata sul mare presenta un volume parallelepipedo caratterizzato da ballatoi aggettanti in legno decorati con pilastri e archi. La struttura è caratterizzata da due corti interne e una possente murazione retrostante che protegge il Monastero dalle frane della montagna. La corte d'ingresso, rivolta a nord accoglie le celle dei monaci, e assolve alle funzioni di filtro per la seconda caratterizzata dalla presenza della chiesa principale risalente alla metà del XVIII sec.

II Monastero di S. Panteleimon, edificato in una zona pianeggiante in riva al mare, è costituito da numerosi edifici quali: un corpo principale di forma rettangolare caratterizzato dalla presenza di alcune strutture quali chiese e cappelle; un edificio a forma di $L$ che segue la linea di costa. Quest'ultimo assolve alla funzione di romitorio per i monaci e i pellegrini che si recano in visita o in preghiera. II Monastero presenta 15 cappelle e numerosi spazi per la realizzazione di oggetti sacri come, ad esempio, una falegnameria. La biblioteca contiene I 320 manoscritti greci e 600 slavi e oltre 20.000 libri greci e russi. Di grande interesse l'utilizzo delle cromie del rosso e del verde nei tetti, ovvero coppi in cotto e superfici in rame che contrastano con il bianco dei paramenti murari adornati con ballatoi e balconi in legno.

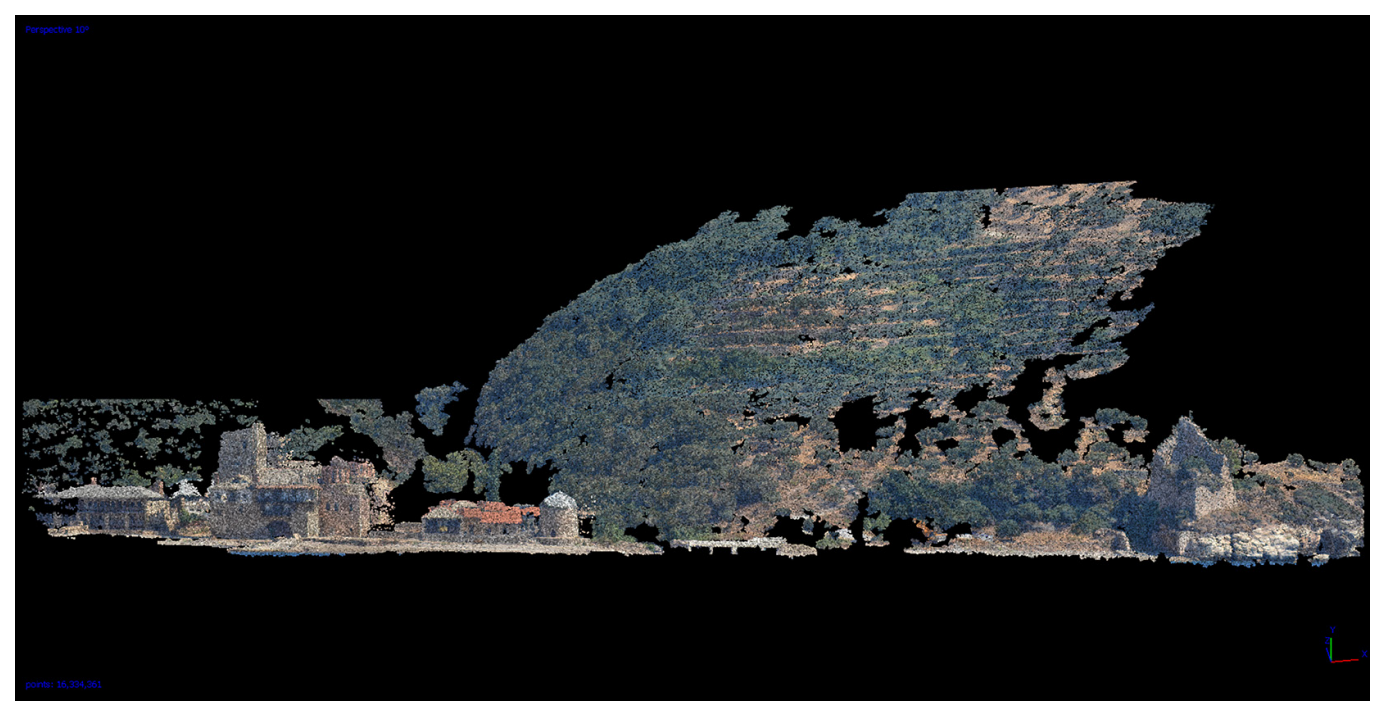



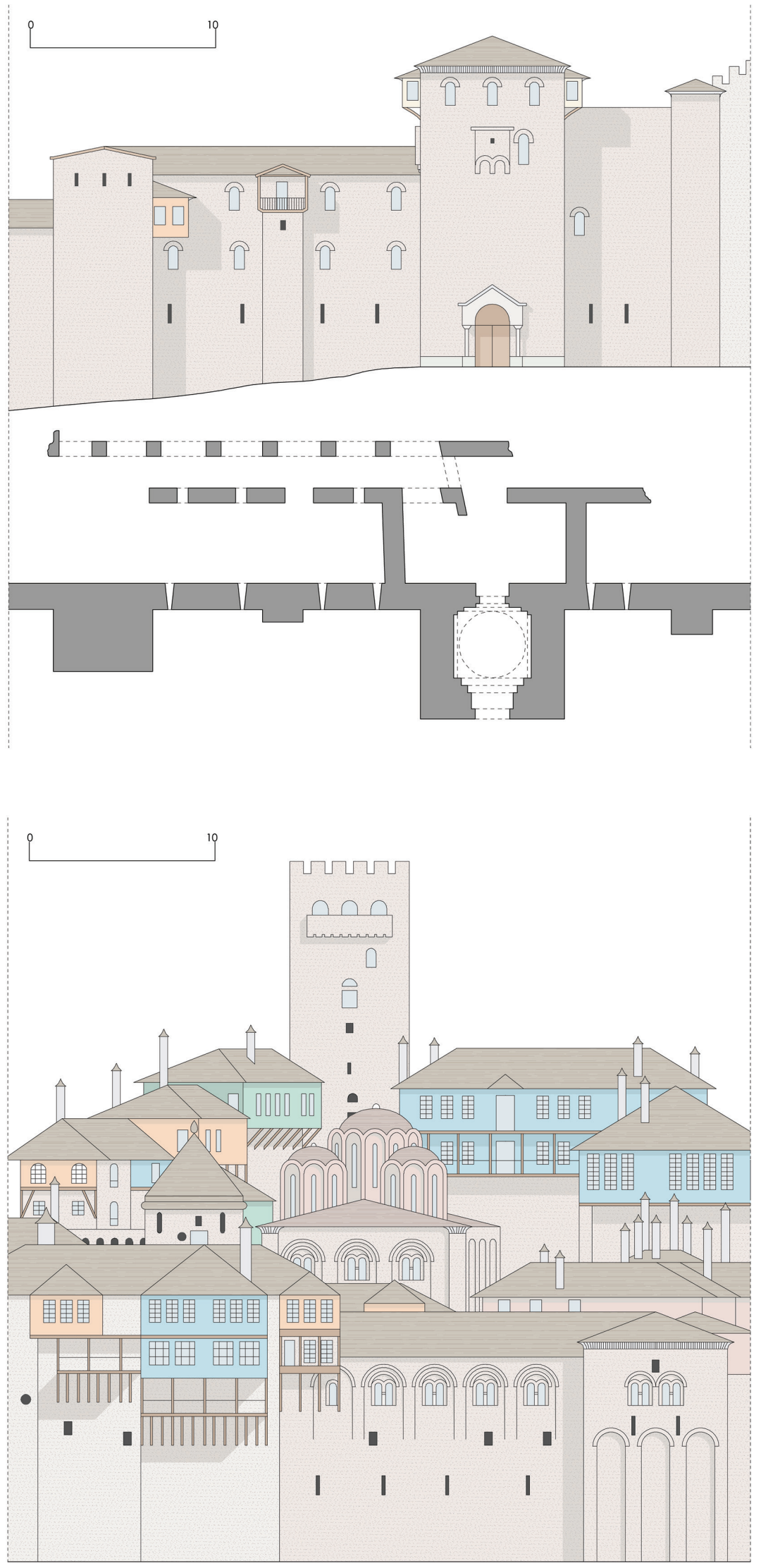
Fig. 10. II Monastero di Simonpetra. Nuvola dei punti realizzata dal mare.

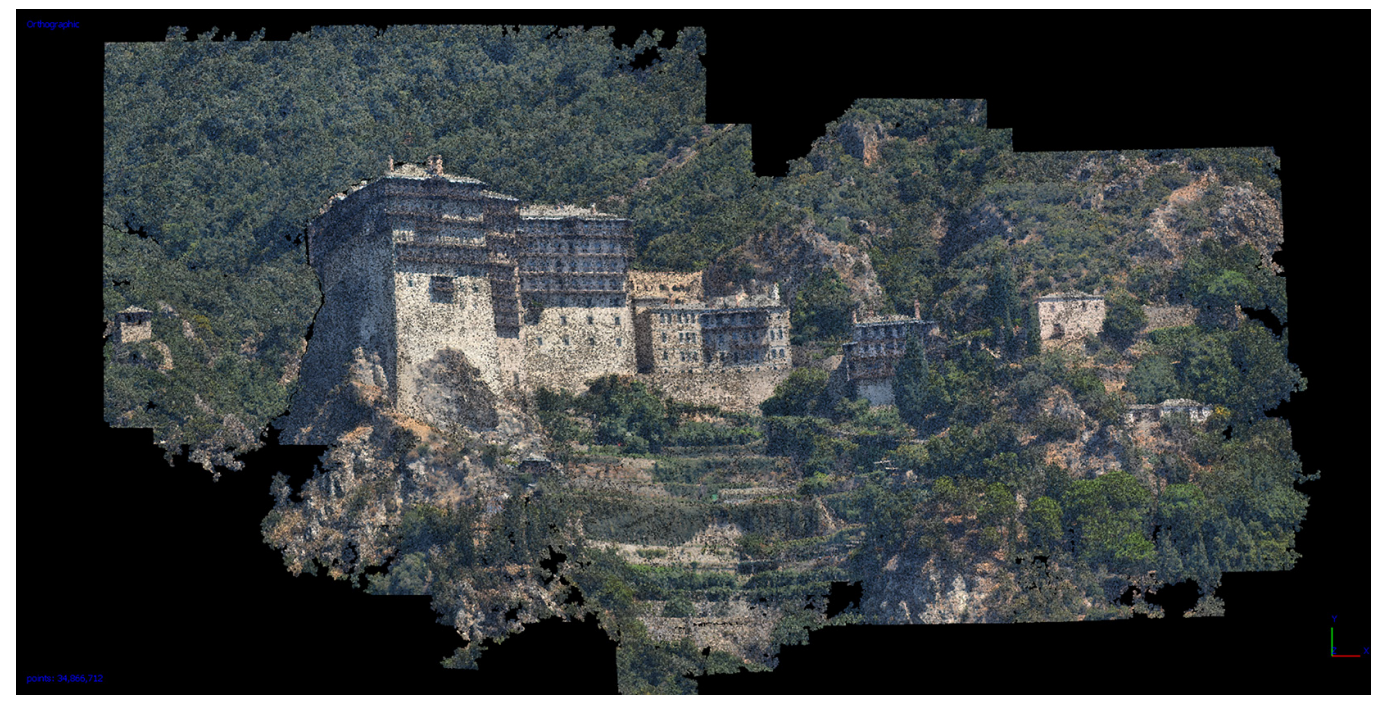

II Monastero di Konstamonitou è sito in una foresta, a 200 metri sopra il livello del mare, a 50 minuti di distanza dalla costa. La realizzazione del piccolo edificio con corte centrale si deve a un eremita che desiderava trascorrere il proprio tempo in solitudine e preghiera a contatto con la natura. L'attuale complesso ha subito numerosi rimaneggiamenti dovuti a ricostruzioni successive a incendi: si individuano quelle del XIV secolo, del I360 e del I 433. A seguito delle ricostruzioni il paramento murario si presenta in pietra locale ed il tetto in cotto rosso riducendo al minimo la presenza di legni in facciata e in copertura. Nella corte è sita la chiesa principale con sei lanterne in copertura rivestite in rame e un piccolo edificio adibito a biblioteca.

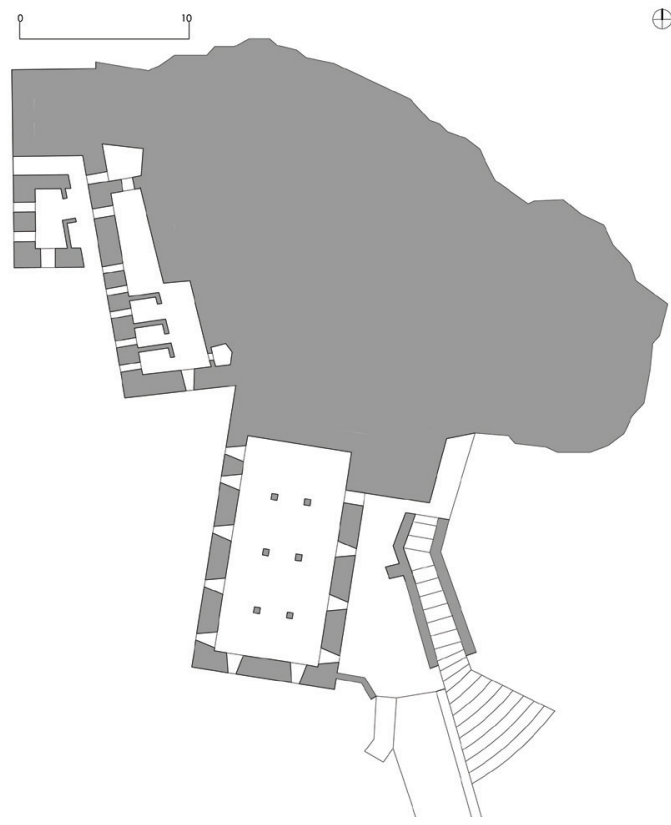

(1)

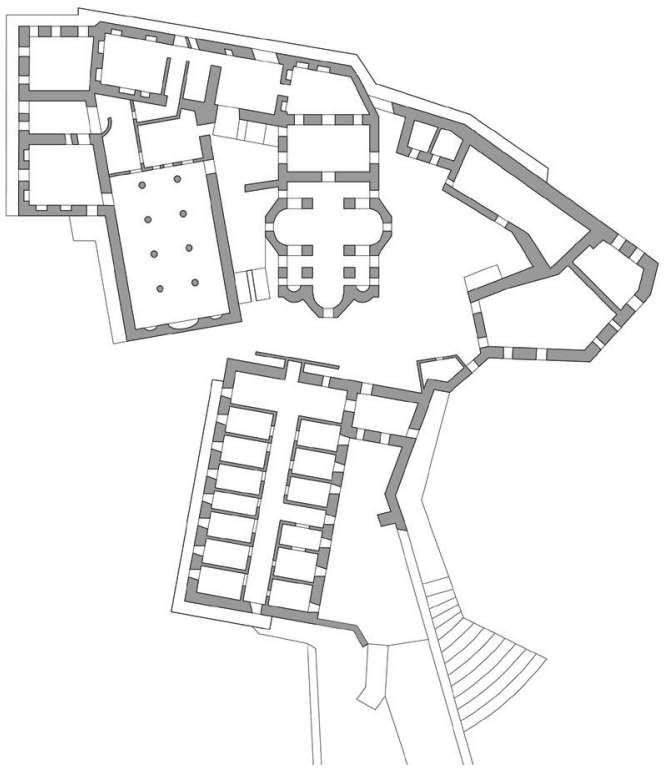




\section{Codici e processi per il rilevo}

Le fasi consolidate della disciplina della rappresentazione, quali rilievo digitale, nuvola dei punti, elaborazione delle superfici piane e modellazione 3D, hanno consentito un percorso di conoscenza del terzo braccio della penisola Calcidica sia relativamente alle architetture religiose, sia in merito alle funzioni attuali e storiche dei dieci monasteri oggetto della ricerca. Le ricerche sono state sviluppate, nella parte iniziale, con documentazione fotografica scattata dal mare, al fine di realizzare un'adeguata campagna illustrativa di documentazione dei manufatti; in una seconda fase, dopo le difficili procedure di visto per l'accesso ai siti, si è proceduto al rilievo in situ dei monasteri della costa occidentale.

Di grande importanza è il progetto delle prese, cioè la definizione dei punti di ripresa dai quali vengono effettuate le misurazioni. Tale progetto ha tenuto conto delle dimensioni effettive dei monasteri sia per la fase svolta dal mare sia per le successive indagini da terra. È stato, quindi, redatto un progetto di rilievo che ha necessitato di maggiore attenzione in quanto era necessaria la sovrapponibilità tra le immagini e il loro corretto allineamento. La caratterizzazione delle riprese ha consentito la definizione di alcune procedure di filtraggio delle immagini al fine di determinare il maggiore abbattimento di rumore e il mantenimento della configurazione geometrica data dalle forme dei monasteri [Apollonio 20 I0].

La dimensione del dettaglio architettonico, costituito spesso da infissi, paramenti murari e ballatoi, ha costituito un ulteriore parametro per la realizzazione delle nuvole di punti sia in

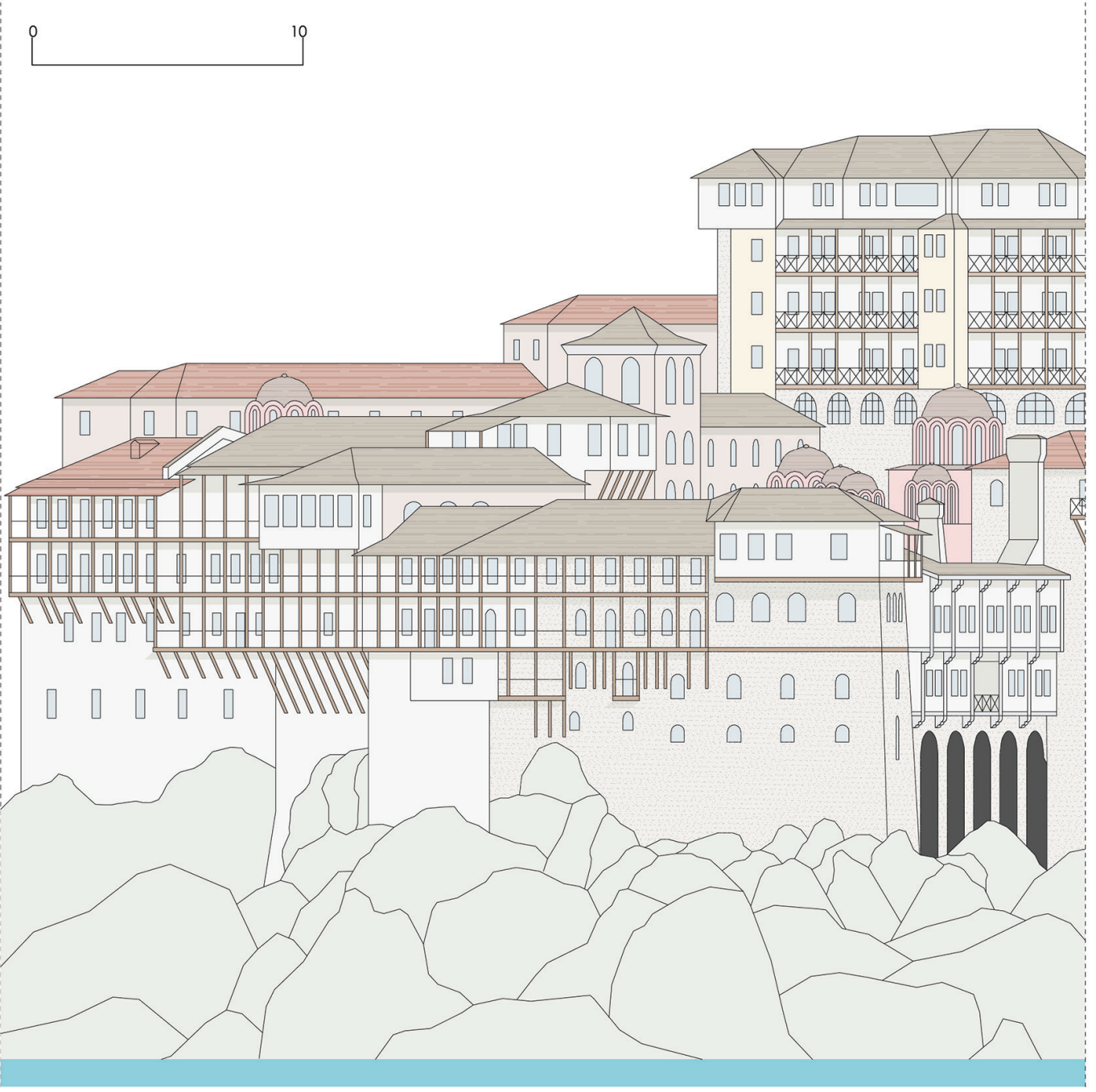


base all'ottica utilizzata sia in relazione alla maglia prestabilita per le fasi del rilievo. In rapporto alla finalità del rilievo, ovvero la documentazione grafico-geometrica, si è tenuto conto delle caratteristiche dimensionali e di occlusione, della riflessione del materiale e del rapporto di dettaglio. La poca libertà di movimento, causata dalle riprese effettuate in barca per cui è stato necessario considerare la relativa oscillazione dovuta al moto ondoso marino, ha notevolmente influito sulla campagna di rilievo e sul processing dei dati raccolti. Le immagini catturate sono state interpolate con misurazioni poste in tre punti diversi. II rilievo è stato eseguito sia dal centro, perpendicolarmente ai singoli monasteri, sia nei punti laterali al fine di raccoglier il maggior numero di triangoli per la realizzazione del modello digitale di rilievo. A seguito della campagna di rilievo dal mare e terrestre, è stato effettuato il processing dei dati raccolti. Di grande importanza è l'allineamento delle immagini attraverso il software digitale. Per il controllo dell'errore la sovrapposizione è stata calcolata nella misura del $40 \%$ tra un'immagine e un'altra con una visione simmetrica da due vertici verso uno stesso punto di presa [Remondino 20I I].

Le immagini ricavate dagli scatti dal mare non hanno evidenziato problemi di scarsa sovrapposizione nella generazione delle mesh, in quanto sia numericamente idonee sia per la condizione di luce. Le mesh sono state fuse in un'unica immagine con caratteristica poligonale. Tale attività ha determinata la creazione di merge immagine della nuvola dei punti. Le geometrie ottenute sono state realizzate utilizzando la densità massima dei vertici dei poligoni riducendo al massimo il controllo automatico delle superfici.

La fase di editing, invece, è stata sviluppata segnando ed eliminando gli errori tipologici relativi all'acquisizione delle immagini, maggiormente per la fase svolta dalla barca, e ai successivi processi di allineamento delle nuvole dei punti. Successivamente, anche se in parte minore, si è reso necessario l'intervento manuale per la chiusura delle lacune presenti nelle superfici meno esposte.

La nuvola dei punti realizzata ha, quindi, subito un controllo del rumore esterno causato dalle molteplici condizioni ambientali presenti in sito. Successivamente sono state realizzate le planimetrie e le sezioni principali al fine di documentare i complessi monastici dell'Athos.

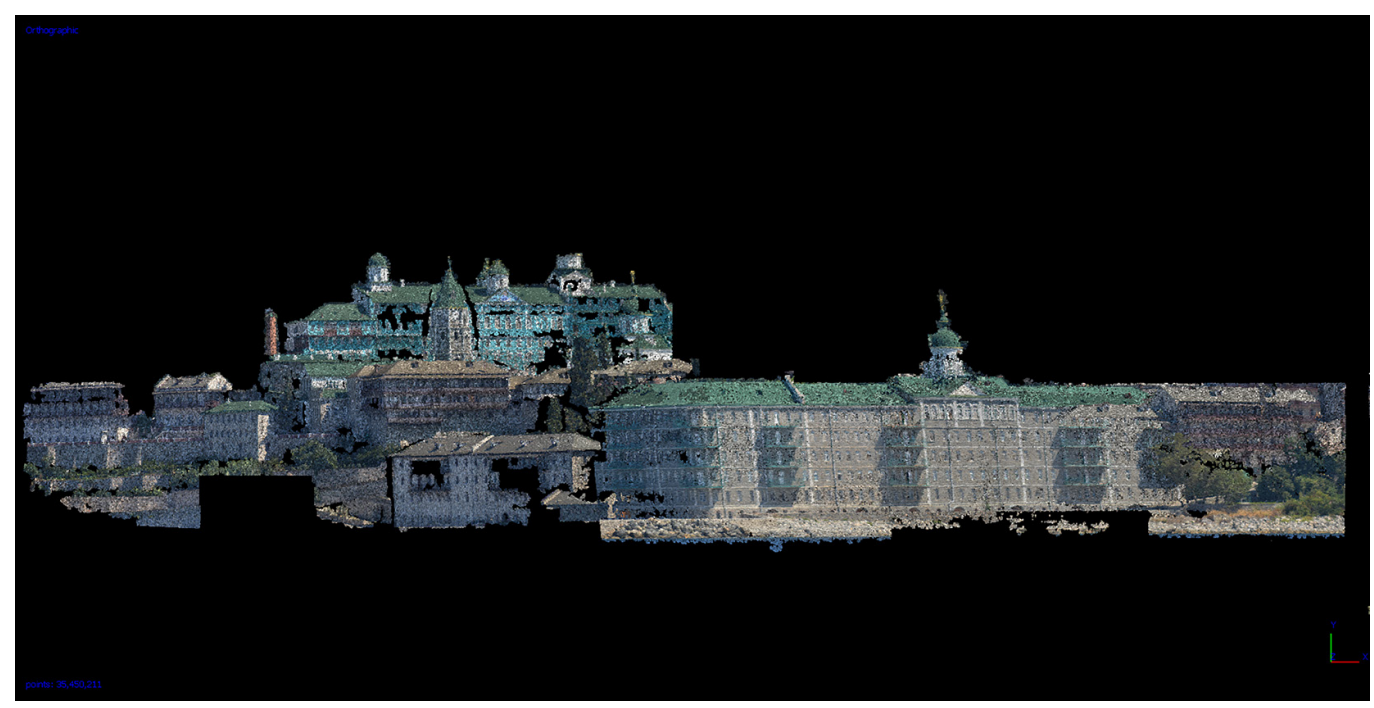

\section{Conclusioni}

Le indagini condotte hanno analizzato, attraverso tecnologie innovative, i codici, overo i linguaggi per la comprensione dell'architettura, gli spazi, ovvero le distanze tra le fasi di conoscenza grafica dei manufatti, e i processi, le fasi utilizzate nell'applicazione delle tecnologie nelle campagne di rilievo. Di grande interesse è il processo operativo illustrato sia in base alle problematiche emerse sia per le soluzioni adottate nelle fasi di conoscenza. 
La ricerca espone, per la prima volta, i rilievi inediti strumentali eseguiti nella comunità dell'Athos, avversa da secoli all'accesso di studiosi, turisti e curiosi.

Le attività di rilievo strumentale, realizzate attraverso l'ausilio di droni quadrielica e fotogrammetria terrestre, hanno interessato la parte occidentale della terza penisola Calcidica owero il Monastero di San Dionisio, il Monastero di Xeropotamo, il Monastero dello Zografo, il Monastero del Dochiario, il Monastero di Simonpetra, il Monastero di San Paolo, il Monastero di Senofonte, il Monastero di San Gregorio, il Monastero di San Pantaleimon e il Monastero di Costamonita. Una conoscenza di linguaggi architettonici analizzati attraverso tecnologie innovative di rilievo per annullare le distanze tra uomo e sapere.

Fig. 15. II Monastero di San Pantaleimon. Particolare del prospetto occidentale.

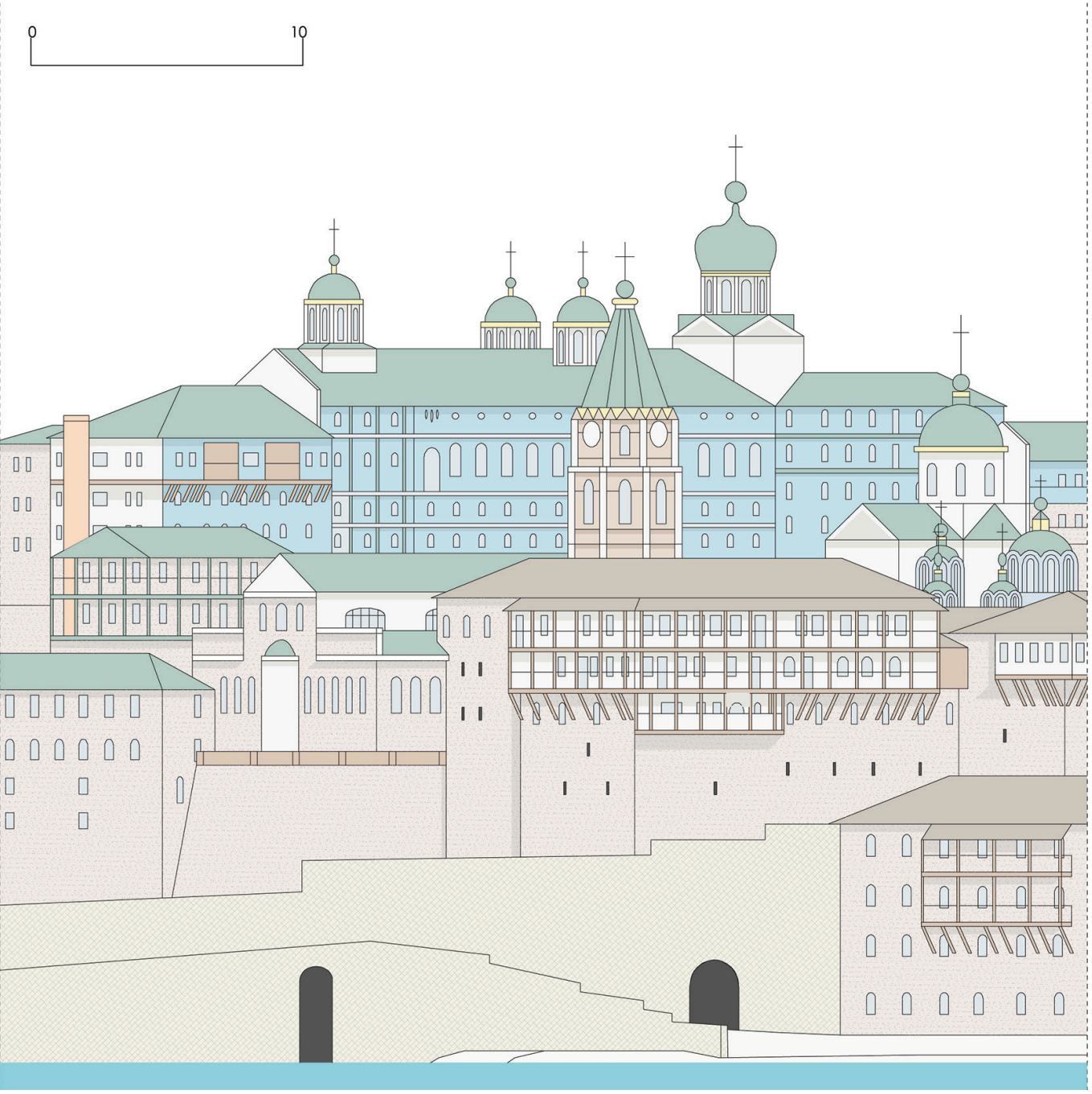

Riferimenti bibliografici

Amoruso G., Apollonio F. I., Remondino F. (20 I 0). Caratterizzazione strumentale di sensori attivi a tempo di volo e a triangolazione. Utilizzo di laser scanner su superfici marmoree di epoca romana. Pisa: Edizioni della Normale.

Apollonio F. I. (20 I 0). La modellazione digitale. Bologna: Clueb.

Barba S., Cardone V. (2013). Modelli grafici dell'architettura e del territorio. Santarcangelo di Romagna: Maggioli.

Bianchini C. (201 I). Rilievo Modellazione e Studio Geometrico delle Cupole. Roma: Edizioni PreProgetti. 
Burridge P. (1994). Architectural development of the Athonite Monastery. In A. Bryer, M. Cunningham (Eds.). Collection of Essays Mount Athos and Byzantine Monasticism. Papers from the Twenty-Eighth Spring Symposium of Byzantine Studies, Birmingham, March 1994, pp. 171- 188. Brookfield: Ashgate Publishing Company.

Capuani M. (1988). Monte Athos. Baluardo monastico del Cristianesimo orientale. Novara: Europìa.

Capuani M. (1997). Il patrimonio artistico. In M. Capuani, M. Paparozzi. Athos, le fondazioni monastiche, un millennio di spiritualità e arte ortodossa. Milano: Jaca Book

Crisan N. (2016). Athos. The Holy Mountain. Suceava: Accent Print.

Della Valle M. (2007). Costantinopoli e il suo impero. Arte, architettura, urbanistica nel millennio bizantino. Milano: Jaca Book.

Farides C. (20 I 0). Monte Santo. Il giardino della Madonna. Salonicco: Rekos.

Manfredini A. M., Remondino,F. (20 I0). Modellazione 3D da immagini. Pipeline fotogrammetrica. Pisa: Edizioni della Normale.

Muresu M. (20I4). Architettura sacra mediobizantina dal Monte Athos (Grecia), il caso di Ravdouchos. In ArcheoArte, n. 3, pp. 27| -293.

Pentzikis G. N. (2003). Mount Athos. Athens: print.

Remondino F. (20 I I). Rilievo e modellazione 3D di siti e architetture complesse. In DisegnareCon, vol. 4, n. 8, pp. 90-98.

Trumler G. (2009). Athos. L'orto della Madonna. Peania: Adam Editions.

\section{Autori}

Luigi Corniello, Università della Campania “Luigi Vanvitelli”, luigi.corniello@unicampania.it

Gennaro Pio Lento, Università della Campania "Luigi Vanvitelli”, gennaropio.lento@unicampania.it

Angelo De Cicco, Università della Campania “Luigi Vanvitelli”, angelo.decicco@unicampania.it

Per citare questo capitolo: Corniello Luigi, Lento Gennaro Pio, De Cicco Angelo (202I). Codici, spazi, processi. I monasteri del Monte Athos/ Codex, spaces, processes. The Monasteries of Mount Athos. In Arena A., Arena M., Mediati D., Raffa P. (a cura di). Connettere. Un disegno pe annodare e tessere. Linguaggi Distanze Tecnologie. Atti del $42^{\circ}$ Convegno Internazionale dei Docenti delle Discipline della Rappresentazione/Connecting. Drawing for weaving relationship. Languages Distances Technologies. Proceedings of the $42^{\text {th }}$ International Conference of Representation Disciplines Teachers. Milano: FrancoAngeli, pp. 566-589. 


\title{
Codex, Spaces, Processes. The Monasteries of Mount Athos
}

\author{
Luigi Corniello \\ Gennaro Pio Lento \\ Angelo De Cicco
}

Abstract

The study proposes the results of the architectural survey campaigns conducted since July 2020 along the western coastal strip of the Athos peninsula in Greece.

The current bibliographic documentation is limited, and most of the books focus on an art-historical description of the paintings in the monasteries, as well as on visitors' travel diaries.

Through the consolidated phases of the discipline of representation, such as digital survey, point clouds, processing of flat surfaces and 3D modelling, a path is proposed to get to know the third arm of the Chalkidiki peninsula with regard to religious architecture.

The initial part of the research was developed with photographic documentation from the sea, while in a subsequent phase the in situ survey of the monasteries on the west coast was carried out.

The instrumental survey activities, carried out with the help of quadrihelix drones and terrestrial photogrammetry, concerned the Monastery of St. Dionysius, the Monastery of Xeropotmus, the Monastery of the Zographer, the Monastery of Dochiario, the Monastery of Simonpetra, the Monastery of St. Paul, the Monastery of Xenophon, the Monastery of St. Gregory, the Monastery of St. Pantaleimon and the Monastery of Costamonita.

The research aims to expose, for the first time, the unpublished instrumental surveys carried out in the Athos community, which has been averse to the access of tourists and curious people for centuries.

Keywords

Survey, Photogrammetry, Technologies, Monasteries, Athos.

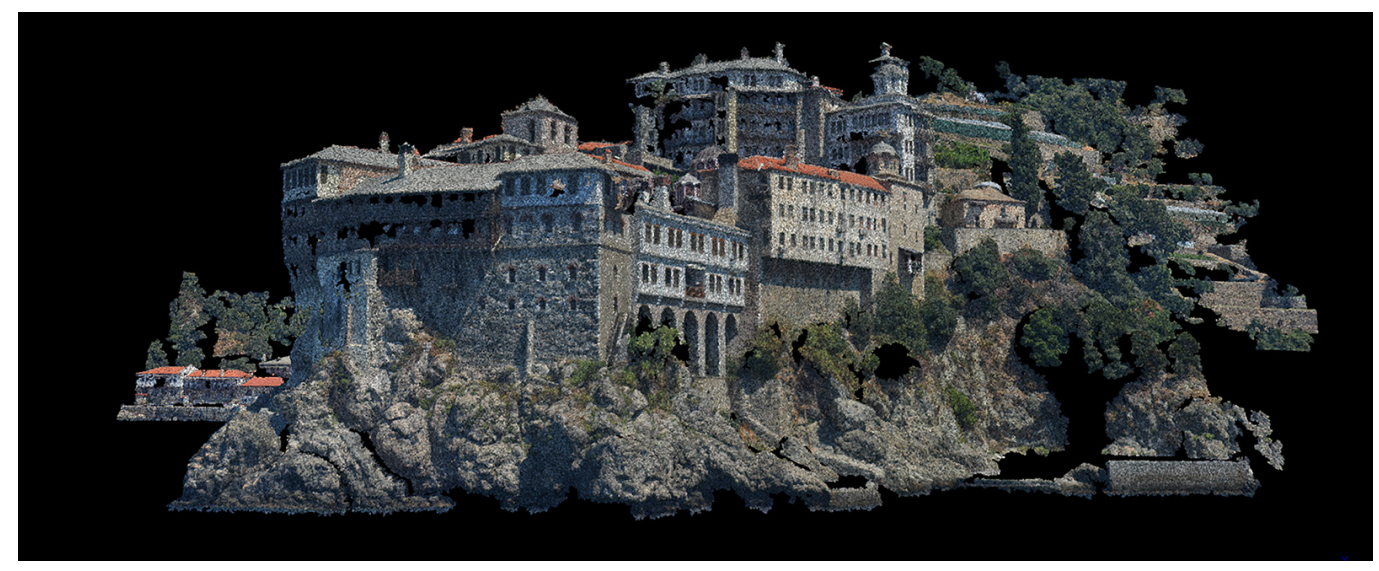




\section{Introduction}

The contribution presents the results of the architectural survey campaigns conducted in July and August 2020 along the western coastal strip of the Mount Athos peninsula, an autonomous territory within the Hellenic Republic but with a special self-governing statute, located at the last of the three peninsulas of the region called Chalkidiki.

The current bibliographic documentation, most of which focuses on a historical and artistic description of the paintings in the monasteries and the travel notes of visitors who have climbed their peaks and steep paths, is limited in its graphic documentation and surveys of the architectural volumes.

Many famous travellers (architects, philosophers, writers, directors) have drawn inspiration for their works from the slopes of the Holy Mountain: the Umberto Eco novel II nome della rosa was inspired by his journey to Athos. Le Corbusier also visited the Mount and some references can be found in his 1960 work, the Catholic Monastery of Tourette in Lyon, France, whose structure can be compared to the monastic complex of Dionisiou. Over the centuries, the monastic community of Athos, dedicated to the hermit life, has preserved the social traditions of the approximately 1500 Orthodox monks and the architectural geometry of the community buildings, churches, service facilities, dormitories and solitary cells.

Fig. I.The monasteries of Mount Athos. Planimetric

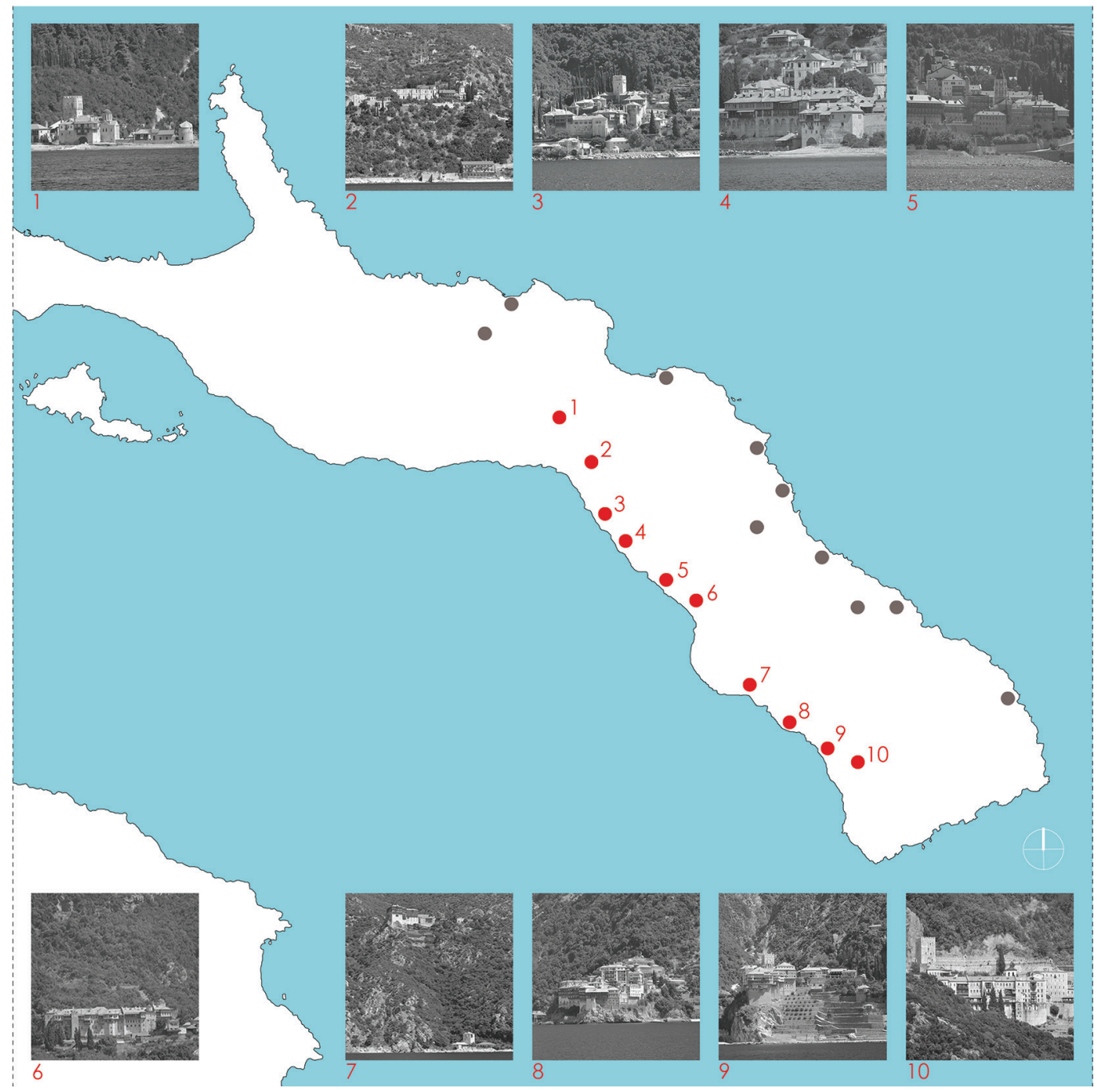




\section{The architectural spaces}

In the definition of the research, the study of the spaces in which monastic life takes place is of particular interest. The activities concerned the Monastery of St. Dionysius, the Monastery of Xeropotmus, the Monastery of Zographus, the Monastery of Dochiarius, the Monastery of Simonpetra, the Monastery of St. Paul, the Monastery of Xenophon, the Monastery of St. Gregory, the Monastery of St. Pantaleimon and the Monastery of Costamonitis.

The Monastery of Dionisiou, built in the middle of the 14th century by the monk Dionysious of Koryssos, was destroyed by fire in 1535 and subsequently rebuilt, retaining its architectural form to this day. The structures, built on a spur of rock overlooking the sea, are smaller than the floor space of the other complexes. The monastery is characterised by a central church surrounded by several chapels with frescoes and a refectory completed in 1603. Of particular interest is the defensive tower, built in 1520, which currently houses the monastery's precious library with numerous works of art including icons and miniature manuscripts.

The Monastery of Xenophontos is located by the sea, between the structures of Docheiariou and St Panteleimonos, and is dedicated to St George. In the historical bibliography it is mentioned in the I I th century, when after a long commercial and cultural activity it was destroyed and rebuilt. The sea-facing part of the building has a large entrance opening,

(1)
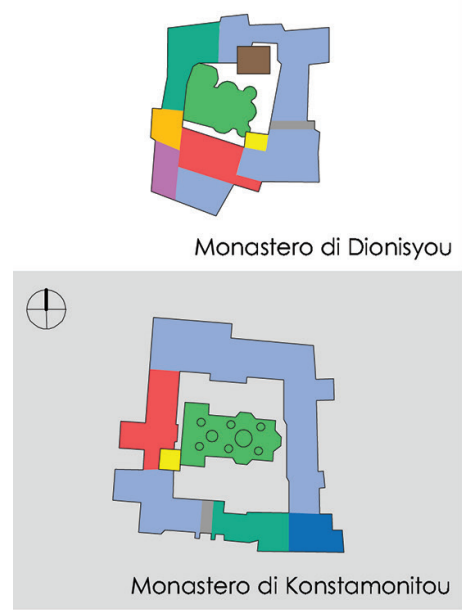

(1)

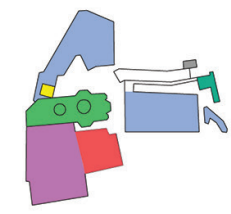

Monastero di Simonos Petras

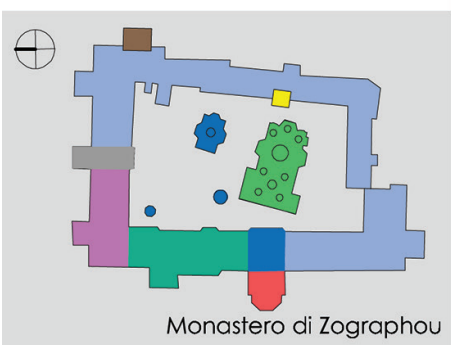

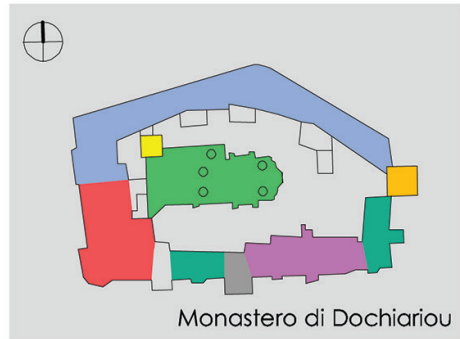

$\theta$
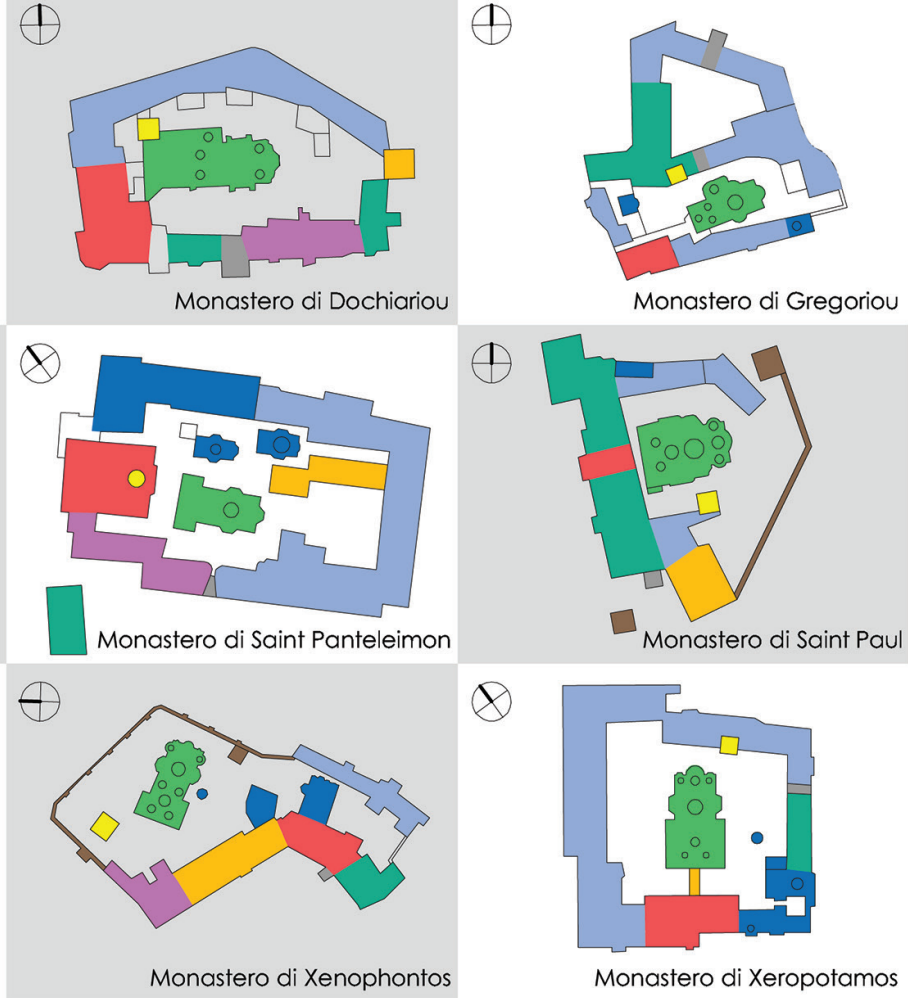

Legenda

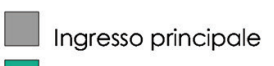

Camere degli ospiti

$\square$ Chiesa principale

Refettorio

Campanile

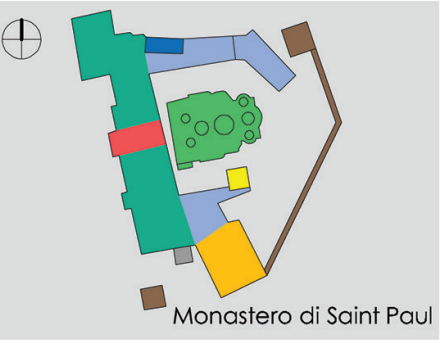

$\otimes$

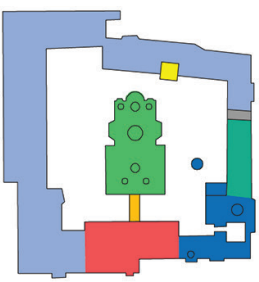

Monastero di Xeropotamos 
Fig. 3.The Monastery of St. Dionysius. Point cloud from the sea.

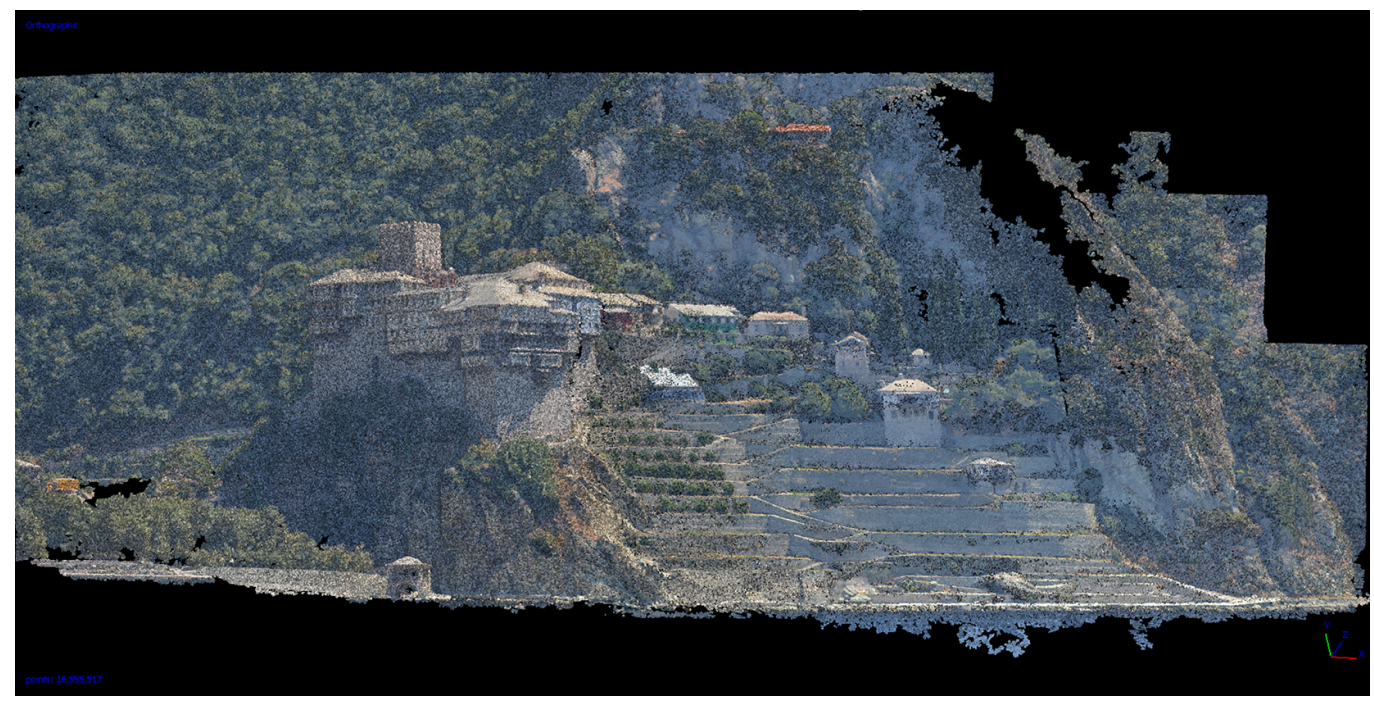

topped by four floors, one of which is attic. The lower part of the building is characterised by a stone structure with arches and buttresses surmounted by wooden galleries coloured red and blue. Of great interest is the library with 300 manuscripts, over 4000 books and numerous mosaic icons.

The Monastery of Zografo, traditionally founded in the IOth century, is dedicated to St George and situated on a slope on the south-west side of the Mount Athos peninsula. In the late Byzantine period it was destroyed by pirates and rebuilt with the financial support of Eastern European rulers. For this reason, the majority of the resident monks came from Bulgaria, Serbia and to some extent, Greece. The volumes in the central courtyard are covered with copper-plated zinc domes. There are also two workshops for painting and making religious icons and a library with 126 manuscripts in Greek and 388 in Slavic. The seaside monastery of Dochiariou was founded in the second half of the IOth century. At present, the structure can be reached by means of a dock for small and medium-sized boats to supply non-self-produced goods. The monastic complex develops on the slope of the mountain with different geometric shapes such as the parallelepipeds of the main volumes, the spheres and hemispheres of the domes of the churches and chapels, the pyramids and cones of the roofs. Of particular note are the two refectories positioned

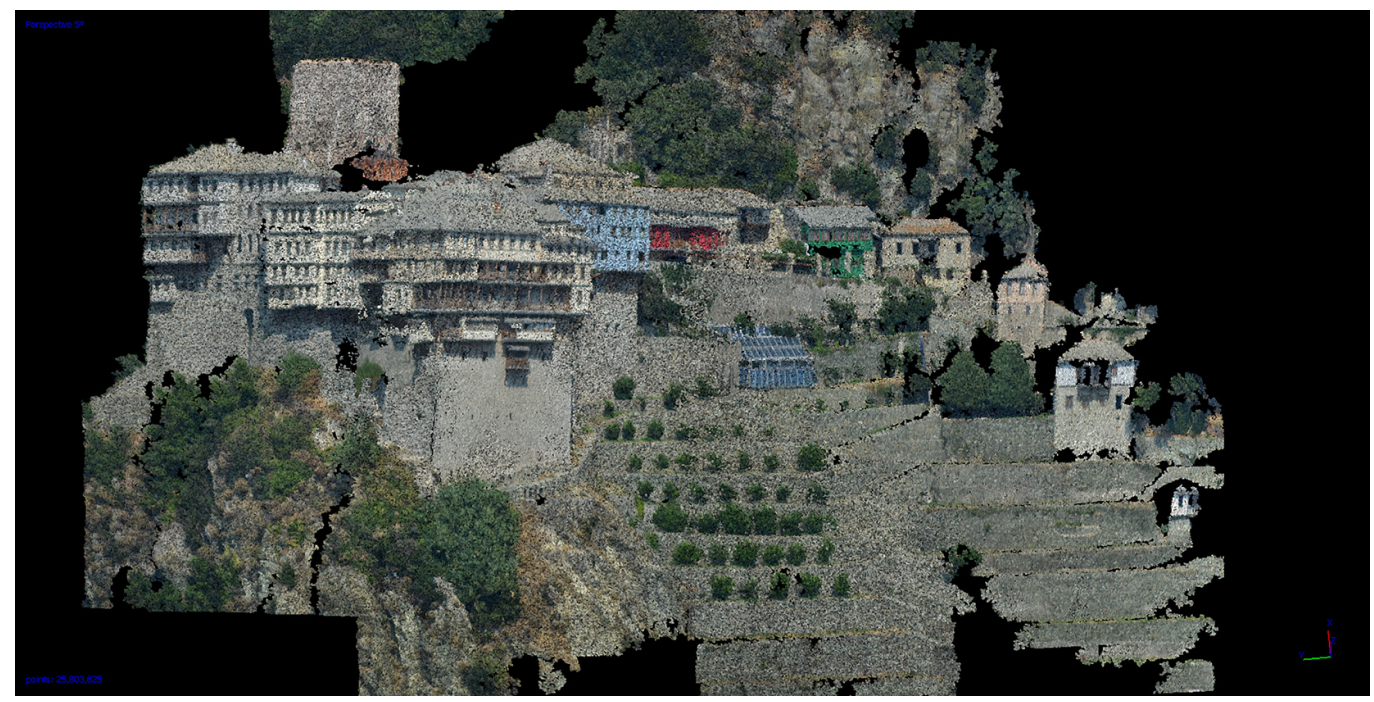

Fig. 4. The Monastery of San Dionisio. Point cloud created by drone. 
parallel to the coastline, with the old refectory by the sea, dating from 1675, and the new one on the hill from 1700, overlooked by the Katholikon, the main church built on the remains of the walls of an older religious building. The monastery also has a watchtower and a library with about 900 manuscripts.

The Simonpetra Monastery is a majestic seven-storey building dedicated to the birth of Christ. The structure is 230 metres above sea level and consists of two architectural complexes, one downstream, which serves as a landing place for boats from the nearby Ouranopoli, and the other upstream, where the monks live and pray. The building by the sea, with a small harbour and boathouse, has a stone watchtower. In a panoramic position, facing south, the Monastery is composed of two built portions: the first with the church, the refectory and a tower; the second, instead, entirely used as a residence for the monks with cells and services. Over the centuries, the building was destroyed by numerous fires and rebuilt several times through donations from Russia.

The Monastery of St Paul, dedicated to the presentation of Christ in the Temple, was destroyed and rebuilt many times over the centuries, and this architectural stratification can be seen in the shapes of the buildings, which date back to different periods. The religious complex, currently attended by a community of 30 monks, has 12 prayer chapels, the most important of which is the one dedicated to St George, with frescoes of the Cretan school dating back to I 555. Of great interest is the library containing 494 manuscripts and a total of about 12500 books.

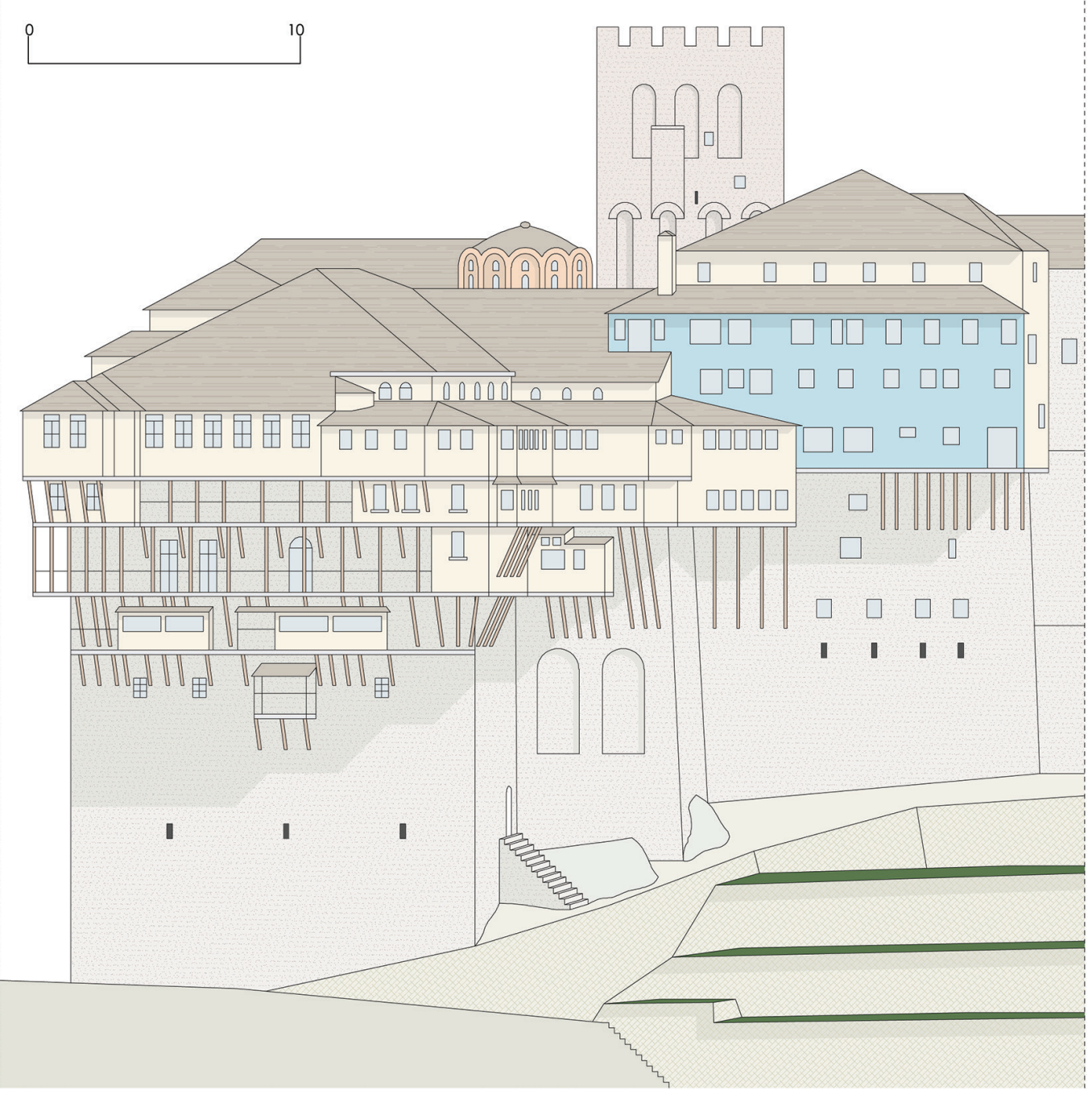




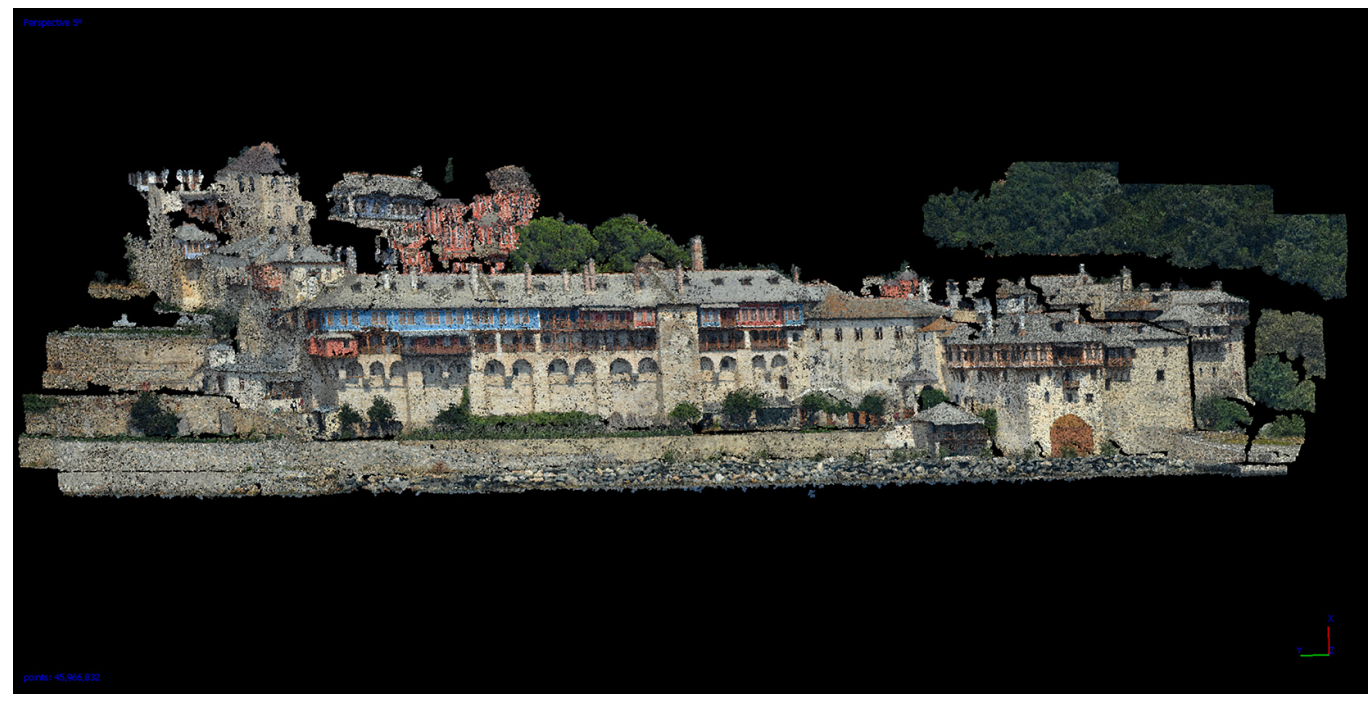

The Monastery of Grigoriou, currently inhabited by a brotherhood of 70 monks, is built by the sea, on the southwest side of the peninsula, between the monasteries of Dionysiou and Simonpetra and is dedicated to St Nicholas. The fifth building by the sea has a parallelepiped volume characterised by projecting wooden galleries decorated with pillars and arches. The structure is characterised by two internal courtyards and an imposing wall at the back that protects the Monastery from landslides from the mountain. The entrance courtyard, facing north, houses the monks' cells and acts as a filter for the second courtyard, characterised by the presence of the main church dating back to the mid- I 8th century.

The Monastery of St. Panteleimon, built on a flat area by the sea, consists of several buildings: a rectangular main body with several structures such as churches and chapels; an L-shaped building that follows the coastline. The latter serves as a hermitage for monks and pilgrims visiting or praying. The Monastery has 15 chapels and numerous spaces for making sacred objects, such as a carpentry shop. The library contains I 320 Greek and 600 Slavic manuscripts and over 20000 Greek and Russian books. Of great interest is the use of red and green colours in the roofs, terracotta tiles and copper surfaces that contrast with the white of the walls adorned with wooden balconies and galleries.

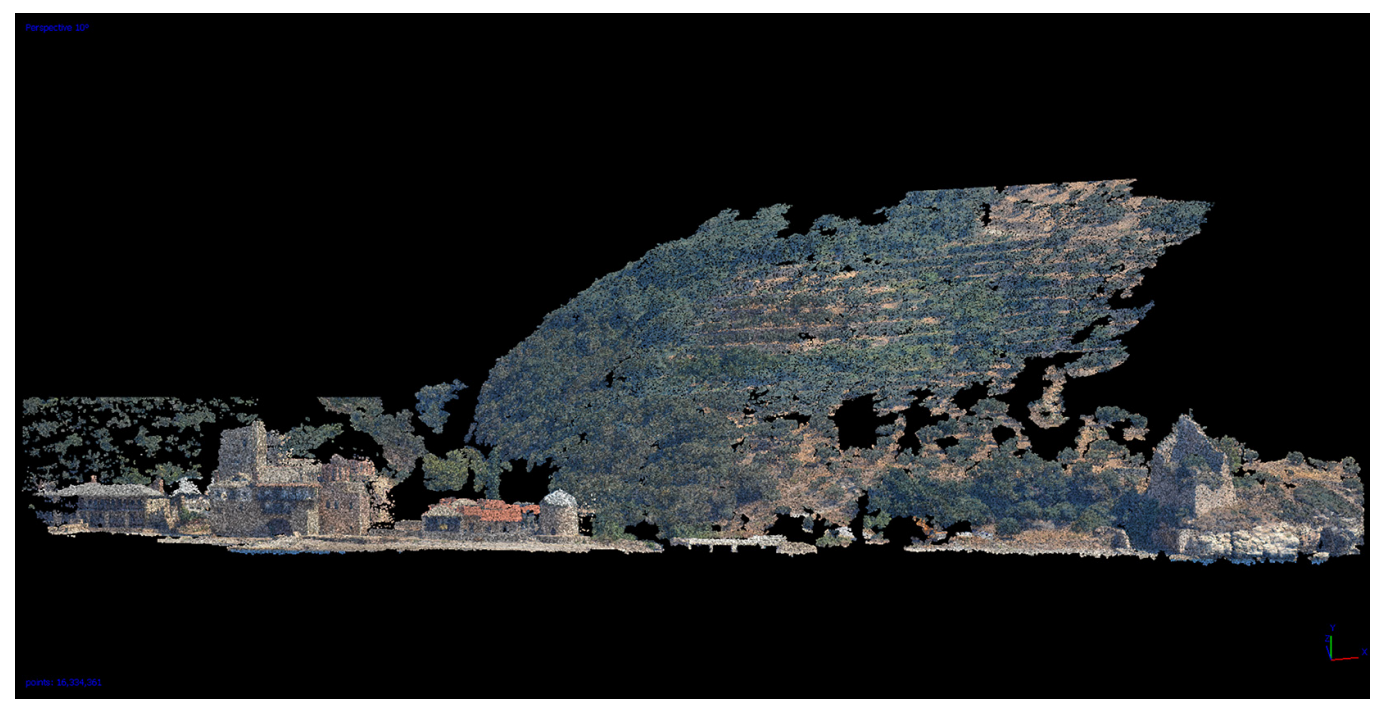



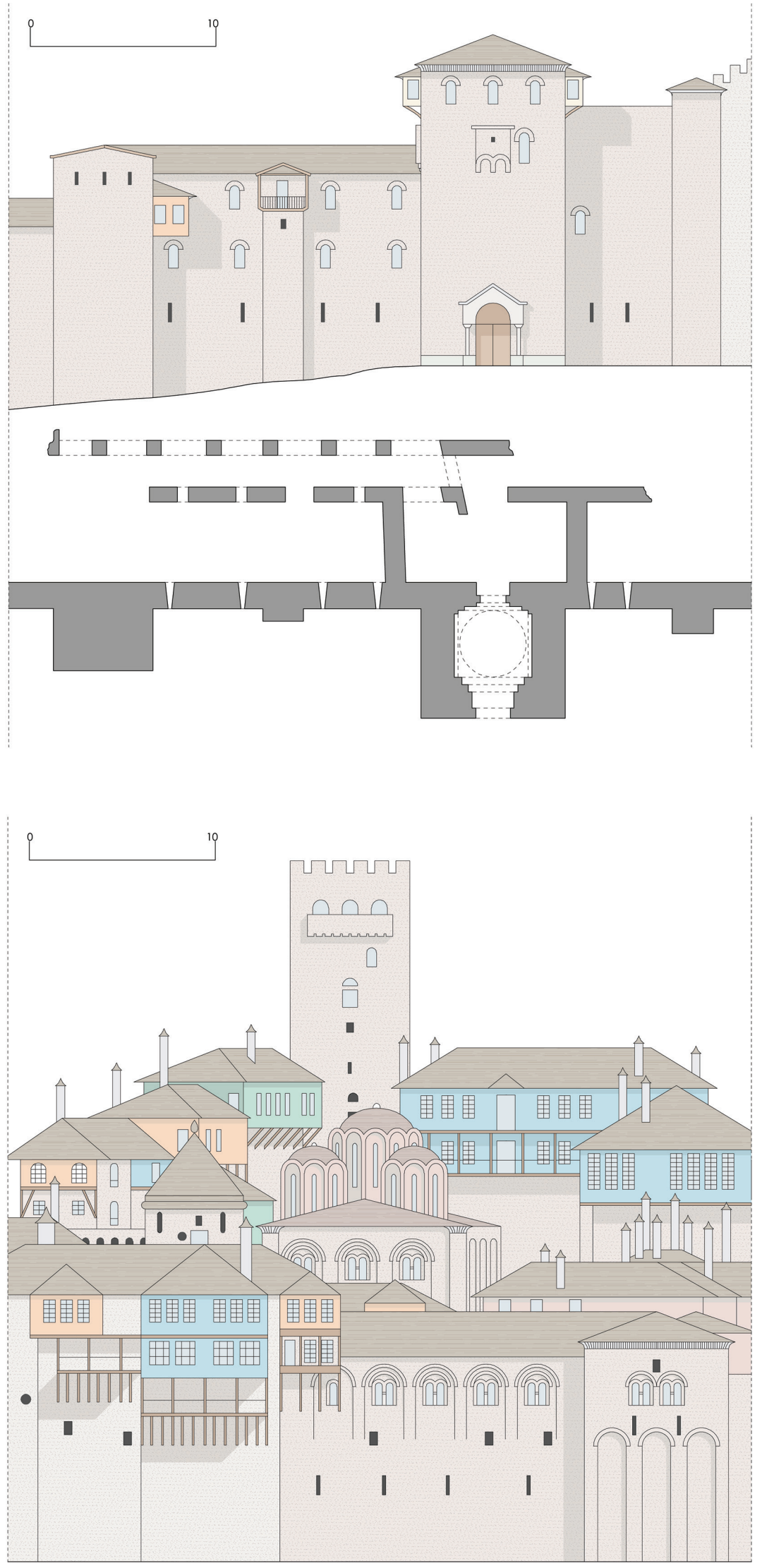


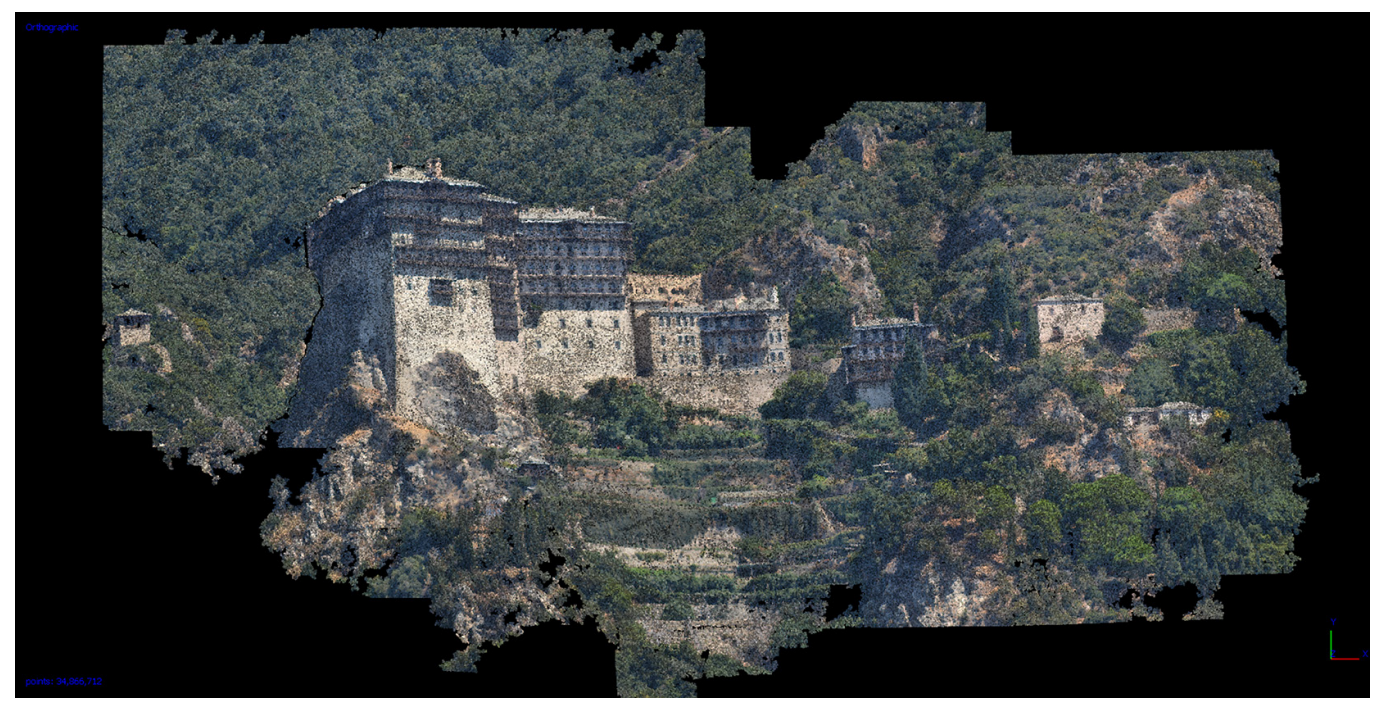

The Konstamonitou Monastery is located in a forest, 200 metres above sea level, 50 minutes away from the coast. The construction of the small building with a central courtyard is due to a hermit who wanted to spend his time in solitude and prayer in contact with nature. The present complex has undergone numerous changes due to reconstructions following fires: those of the |4th century, I 360 and |433. Following the reconstructions, the wall face is in local stone and the roof in red brick, reducing the presence of wood on the facade and roof to a minimum. In the courtyard is the main church with six copper-clad roof lanterns and a small library building.

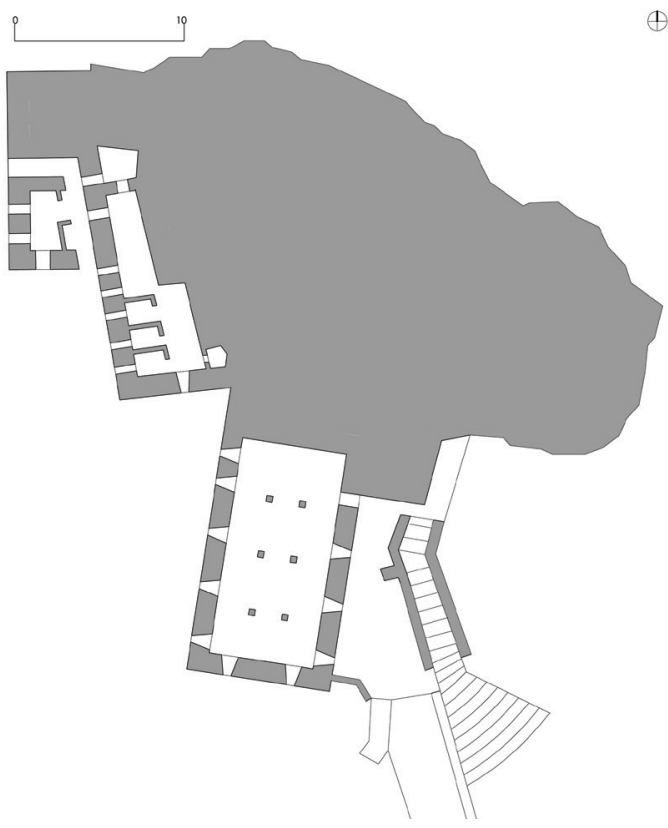

(1)

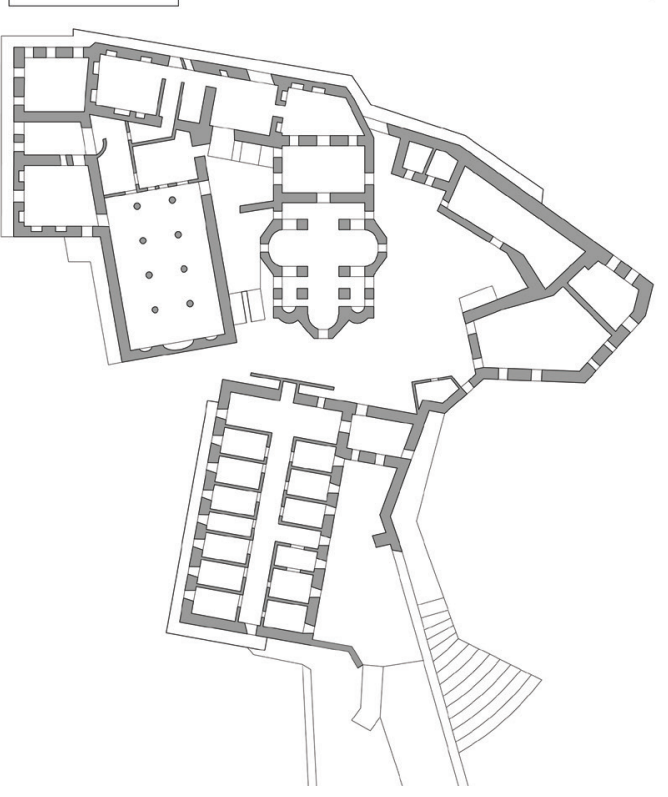




\section{Codes and processes for surveying}

The consolidated phases of the discipline of representation, such as digital surveying, point clouds, processing of flat surfaces and 3D modelling, have enabled a journey of knowledge of the third arm of the Chalkidiki peninsula, both with regard to the religious architecture and to the current and historical functions of the ten Monasteries under research.

The research was developed, in the initial part, with photographic documentation taken from the sea, in order to create an appropriate illustrative campaign to document the artefacts. In a second phase, after the difficult visa procedures for access to the sites, the in situ survey of the Monasteries on the west coast was carried out.

Of great importance is the design of the sockets, the definition of the shooting points from which the measurements are taken. This project took into account the actual dimensions of the Monasteries both for the phase carried out from the sea and for the subsequent surveys from land. A survey project was then drawn up which required greater attention as it was necessary to superimpose the images and align them correctly. The characterisation of the shots allowed the definition of some image filtering procedures in order to determine the greatest reduction in noise and the maintenance of the geometric configuration given by the shapes of the Monasteries [Apollonio 20 I0].

The size of the architectural detail, often consisting of fixtures, wall facings and balconies, constituted a further parameter for the realisation of the point clouds both on the basis

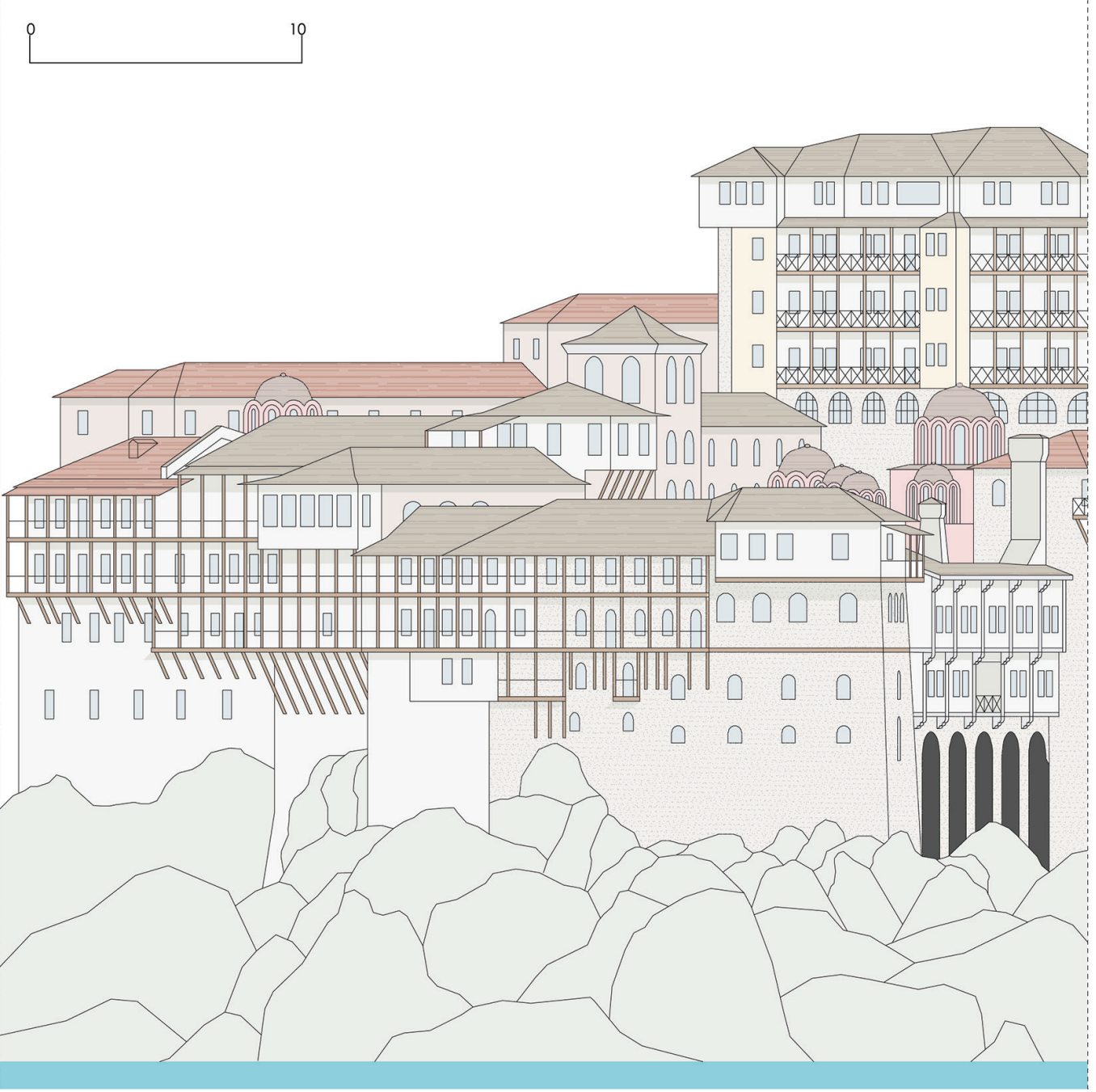


of the optics used and in relation to the mesh established for the survey phases. In relation to the purpose of the survey, graphic-geometric documentation, the dimensional and occlusion characteristics, the reflection of the material and the detail ratio were taken into account. The lack of freedom of movement, caused by the filming carried out by boat, for which it was necessary to take into account the relative oscillation due to the sea waves, greatly influenced the survey campaign and the processing of the data collected. The captured images were interpolated with measurements taken at three different points. The survey was carried out both from the centre, perpendicular to the individual monasteries, and the side points in order to collect the greatest number of triangles for the creation of the digital survey model.

Following the sea and land survey campaign, processing of the collected data was carried out. Of great importance is the alignment of the images through the digital software. In order to control the error, the overlap was calculated to the extent of $40 \%$ between one image and another with a symmetrical view from two vertices towards the same point of capture [Remondino 20I I].

The images taken from the sea shots did not show any problems of poor overlap in mesh generation, as they were both numerically suitable for the light condition. The meshes were merged into a single image with polygonal characteristics. This activity resulted in the creation of merge images of the point cloud. The geometries obtained were realised using the maximum density of the polygon vertices, reducing the automatic control of the surfaces to a maximum.

The editing phase, on the other hand, was developed by marking and eliminating typological errors relating to the acquisition of the images, mainly for the phase carried out by the boat, and the subsequent point cloud alignment processes. Subsequently, although to a lesser extent, manual intervention was necessary to close the gaps present in the less exposed surfaces.

The point cloud created was then checked for external noise caused by the multiple environmental conditions present on site. Subsequently, the plans and main sections were created in order to document the monastic complexes of Athos.

Fig. 14. The Monastery of San Pantaleimon. Cloud

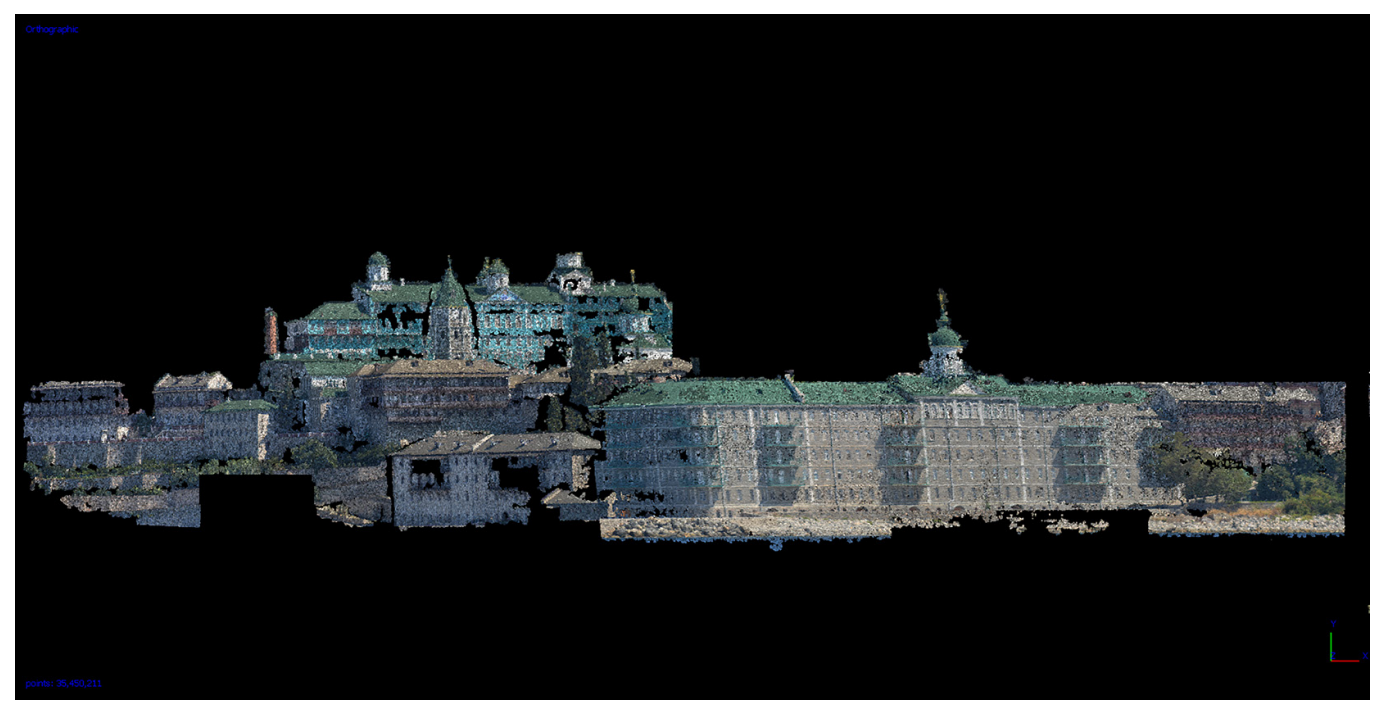

\section{Conclusions}

The investigations conducted have analysed, through innovative technologies, the codes, the languages for understanding architecture, the spaces, the distances between the phases of graphic knowledge of the artefacts, and the processes, the phases used in the application of the technologies in the survey campaigns. Of great interest is the operational 
process illustrated both on the basis of the problems that emerged and the solutions adopted in the knowledge phases.

The research exposes, for the first time, the unpublished instrumental surveys carried out in the Athos community, which for centuries has been denied access to scholars, tourists and the curious.

The instrumental survey activities, carried out with the aid of quadrihelix drones and terrestrial photogrammetry, concerned the western part of the third Chalkidiki peninsula, namely the Monastery of St. Dionysius, the Monastery of Xeropothemus, the Monastery of Zographos, the Monastery of Dochiario, the Monastery of Simonpetra, the Monastery of St. Paul, the Monastery of Xenophon, the Monastery of St. Gregory, the Monastery of St. Pantaleimon and the Monastery of Costamonita. A knowledge of architectural languages analysed through innovative surveying technologies to cancel the distances between man and knowledge.

Fig. 15. The Monastery of St Pantaleimon. Detail of the western elevation.

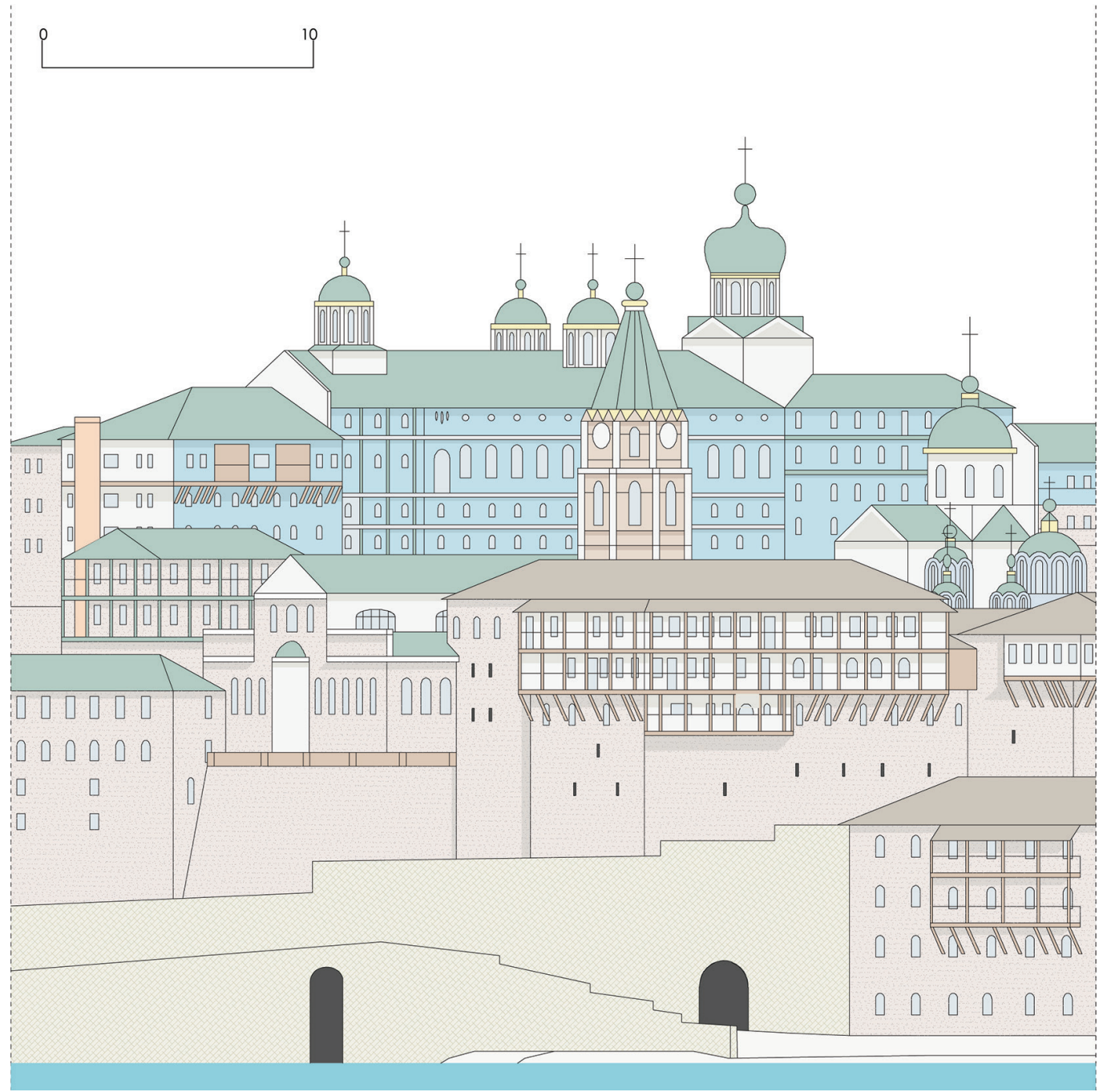

\section{References}

Amoruso G.,Apollonio F. I., Remondino F. (20 I 0). Caratterizzazione strumentale di sensori attivi a tempo di volo e a triangolazione. Utilizzo di laser scanner su superfici marmoree di epoca romana. Pisa: Edizioni della Normale.

Apollonio F. I. (20I0). La modellazione digitale. Bologna: Clueb.

Barba S., Cardone V. (20।3). Modelli grafici dell'architettura e del territorio. Santarcangelo di Romagna: Maggioli.

Bianchini C. (20I I). Rilievo Modellazione e Studio Geometrico delle Cupole. Roma: Edizioni PreProgetti. 
Burridge P. (1994). Architectural development of the Athonite Monastery. In A. Bryer, M. Cunningham (Eds.). Collection of Essays Mount Athos and Byzantine Monasticism. Papers from the Twenty-Eighth Spring Symposium of Byzantine Studies, Birmingham, March 1994, pp. 171- 188. Brookfield: Ashgate Publishing Company.

Capuani M. (1988). Monte Athos. Baluardo monastico del Cristianesimo orientale. Novara: Europìa.

Capuani M. (1997). Il patrimonio artistico. In M. Capuani, M. Paparozzi. Athos, le fondazioni monastiche, un millennio di spiritualità e arte ortodossa. Milano: Jaca Book

Crisan N. (2016). Athos. The Holy Mountain. Suceava: Accent Print.

Della Valle M. (2007). Costantinopoli e il suo impero. Arte, architettura, urbanistica nel millennio bizantino. Milano: Jaca Book.

Farides C. (20 I 0). Monte Santo. Il giardino della Madonna. Salonicco: Rekos.

Manfredini A. M., Remondino,F. (20 I0). Modellazione 3D da immagini. Pipeline fotogrammetrica. Pisa: Edizioni della Normale.

Muresu M. (20I4). Architettura sacra mediobizantina dal Monte Athos (Grecia), il caso di Ravdouchos. In ArcheoArte, n. 3, pp. 27| -293.

Pentzikis G. N. (2003). Mount Athos. Athens: print.

Remondino F. (20 I I). Rilievo e modellazione 3D di siti e architetture complesse. In DisegnareCon, vol. 4, n. 8, pp. 90-98.

Trumler G. (2009). Athos. L'orto della Madonna. Peania: Adam Editions.

\author{
Authors \\ Luigi Corniello, Università della Campania “Luigi Vanvitelli", luigi.corniello@unicampania.it \\ Gennaro Pio Lento, Università della Campania “Luigi Vanvitelli", gennaropio.lento@unicampania.it \\ Angelo De Cicco, Università della Campania “Luigi Vanvitelli”, angelo.decicco@unicampania.it
}

To cite this chapter. Corniello Luigi, Lento Gennaro Pio, De Cicco Angelo (202I). Codici, spazi, processi. I monasteri del Monte Athos/Codex, spaces, processes. The Monasteries of Mount Athos. In Arena A., Arena M., Mediati D., Raffa P. (a cura di). Connettere. Un disegno per annodare e tessere. Linguaggi Distanze Tecnologie. Atti del $42^{\circ}$ Convegno Internazionale dei Docenti delle Discipline della Rappresentazione/Connecting. Drawing for weaving relationship. Languages Distances Technologies. Proceedings of the $42^{\text {th }}$ International Conference of Representation Disciplines Teachers. Milano: FrancoAngeli, pp. 566-589. 